US Army Corps

of Engineers $S_{\circledast}$

Engineer Research and

Development Center

Aquatic Plant Control Research Program

Vegetation Community Changes in Response to Phragmites Management at Times Beach, Buffalo, New York

Aaron N. Schad, Gary O. Dick, Kris Erickson, Paul Fuhrmann,

September 2021

and Lynde L. Dodd 
The U.S. Army Engineer Research and Development Center (ERDC) solves the nation's toughest engineering and environmental challenges. ERDC develops innovative solutions in civil and military engineering, geospatial sciences, water resources, and environmental sciences for the Army, the Department of Defense, civilian agencies, and our nation's public good. Find out more at www.erdc.usace.army.mil.

To search for other technical reports published by ERDC, visit the ERDC online library at https://erdclibrary.on.worldcat.org/v2. 


\title{
Vegetation Community Changes in Response to Phragmites Management at Times Beach, Buffalo, New York
}

\author{
Aaron N. Schad, Gary O. Dick, and Lynde L. Dodd \\ Environmental Laboratory \\ U.S. Army Engineer Research and Development Center \\ 3909 Halls Ferry Road \\ Vicksburg, MS 39180-6199 \\ Kris Erickson and Paul Fuhrmann \\ Ecology and Environment, Inc. \\ 368 Pleasant View Drive \\ Lancaster, NY 14086
}

Final report

Approved for public release; distribution is unlimited.

Prepared for U.S. Army Corps of Engineers

Washington, DC 20314-1000

Under Funding Account Code U4351109; AMSCO Code 099993 


\section{Abstract}

Management of invasive phragmites (Phragmites australis [Cav.] Trin. Ex Steud.) in the United States has proven challenging over the last several decades. Various methods for control exist, but integrated approaches appear to have the most success. However, documentation of vegetation community-wide responses to these approaches remains limited.

This study monitored plant community changes at Times Beach, New York, over a five-year period. In concert with mowing and thatch removal in all areas, the study evaluated two herbicides separately and together, representing three experimental treatment areas (TAs), for control efficacy by measuring plant community structure. Phragmites was targeted for treatments, avoiding native and nonproblematic non-native species when possible, to preserve beneficial habitat during phragmites control efforts. Monitoring results showed significant drops in phragmites relative cover, relative frequency, and importance values due to integrated management, regardless of herbicide treatment, with corresponding increases in these same values for native and other plant species. This suggests that prudent removal of phragmites is compatible with beneficial plant restorative efforts to maintain and improve habitat in infested areas.

DISCLAIMER: The contents of this report are not to be used for advertising, publication, or promotional purposes. Citation of trade names does not constitute an official endorsement or approval of the use of such commercial products. All product names and trademarks cited are the property of their respective owners. The findings of this report are not to be construed as an official Department of the Army position unless so designated by other authorized documents. 


\section{Contents}

Abstract............................................................................................................................................. ii

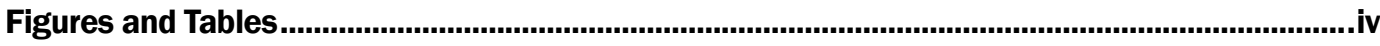

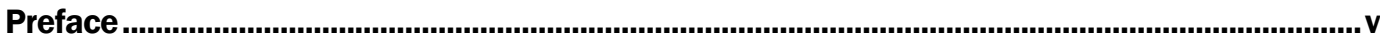

1 Introduction............................................................................................................................. 1

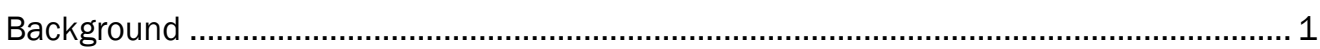

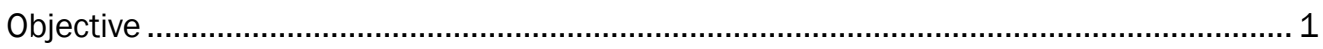

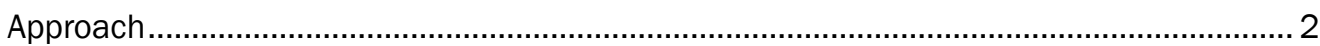

2 Materials and Methods............................................................................................................. 5

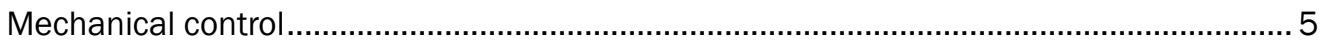

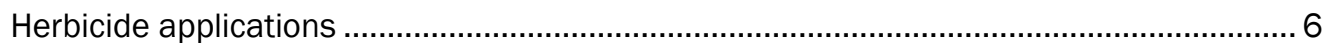

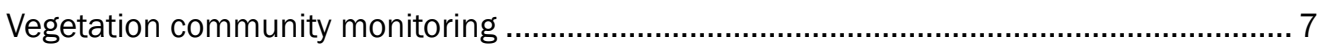

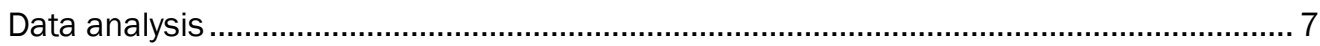

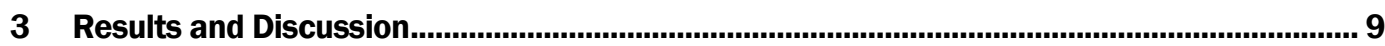

References.............................................................................................................................15

Appendix A: Times Beach Seed Bank Species Data Collected in 2011 ...................................17

Appendix B: Vegetation Species and Groupings Identified Along Six Transects at

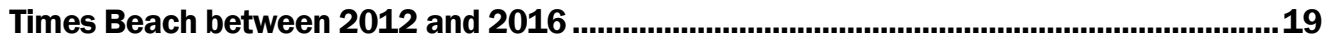

Appendix C: Relative Cover, Relative Frequency, and Importance Value Calculated for Vegetation Transects in Three Treatment Areas (TAs) at Times Beach, New York..............22

Appendix D: Nonmetric Multidimensional Scaling (NMDS) Ordination of Sampling Sites Based on Vegetation Relative Cover with Bubble Plot Overlay Showing Mean Vegetation Cover Class at Each Sampling Location

Report Documentation Page 


\section{Figures and Tables}

\section{Figures}

Figure 1. Times Beach (bordered in white) is a 22.7-hectare confined disposal facility located near the mouth of the Buffalo River in Buffalo, New York. (Photo credit: Google Earth)......

Figure 2. The 5.7 ha emergent marsh portion of Times Beach was divided into three treatment areas (TAs) for evaluation of different herbicide applications during two years of the five-year project. (Photo credit: Google Earth)..

Figure 3. Dendrogram of 15 sampling sites (three TAs times five years) based on cluster analysis of vegetation relative cover (Bray-Curtis) similarity at Times Beach, New York (2012-2016)

Figure 4. Relative cover of 15 sampling sites (TAs $\times$ year) at Times Beach, New York, (2012-2016) on first two dimensions from nonmetric multidimensional scaling (NMDS). Bray-Curtis similarity of 70,80 , and $90 \%$ resemblance similarity levels are given.

Figure 5. Dendrogram of 15 sampling sites (three TAs times five years) based on cluster analysis of vegetation relative frequency (Bray-Curtis) similarity at Times Beach, New York (2012-2016)

Figure 6. Relative frequency of 15 sampling sites (three TAs times five years) at Times Beach, New York, (2012-2016) on first two dimensions from NMDS. Bray-Curtis similarity of 70,80 , and $90 \%$ resemblance similarity levels are given.

Figure 7. Dendrogram of 15 sampling sites (three TAs times five years) based on cluster analysis of vegetation importance value (Bray-Curtis) similarity at Times Beach, New York (2012-2016)

Figure 8. Importance Values of 15 sampling sites (three TAs times five years) on first two dimensions from NMDS. Bray-Curtis similarity of 70,80 , and $90 \%$ resemblance similarity levels are given.

Figure 9. Importance values (IV) for seven groups of vegetation identified along transects over a five-year period at Times Beach, New York. Year 1 was baseline.

Figure 10. Times Beach phragmites infestation in fall 2012 (top), prior to management, and in fall 2017 (bottom) following five years of management. (Photo credit: Gary Dick).

\section{Tables}

Table 1. Herbicide applications at Times Beach, New York.

Table 2. Transects used for vegetation community monitoring at Times Beach 20122016.

Table 3. Number of plant taxa identified along transects at Times Beach, New York, in Years 1-5 (2012-2015). 


\section{Preface}

This study was conducted for the Aquatic Plant Control Research Program (APCRP) under Funding Account Code U4351109 and AMSCO Code 099993. The APCRP is sponsored by Headquarters, US Army Corps of Engineers (HQUSACE), and is assigned to the US Army Engineer Research and Development Center (ERDC) under the purview of the Environmental Laboratory (EL), Vicksburg, Mississippi. The APCRP Program Manager was Dr. Linda Nelson.

The authors would like to thank Judy Shearer (EL), LeeAnn Glomski (EL), and Christina Rockwell (Ecology and Environment, Inc.) for their substantial contributions to this project. The authors would also like to thank Ms. Julie Nachtrieb, Dr. Kurt Getsinger, and Dr. Christopher Mudge for their reviews and comments on this document. Support for this project was provided by the Great Lakes Restoration Initiative (GLRI) via the US Army Corps of Engineers Buffalo District and conducted under the authority of the Aquatic Plant Control Research Program (APCRP). Permission to publish on this information was granted by the Chief of Engineers. Citation of trade names does not constitute an official endorsement or approval of the use of such products.

This report was prepared under the general supervision of Alan Katzenmeyer, Chief, Aquatic Ecology and Invasive Species Branch; Mr. Mark D. Farr, Chief, Ecosystem Evaluation and Engineering Division; and Dr. Edmund Russo, Director, EL.

At the time of the publication of this report, COL Teresa Schlosser was the Commander of ERDC, and Dr. David W. Pittman was the Director.

POINTS OF CONTACT: For additional information, contact the author, Aaron N. Schad, 210-379-2936, Aaron.N.Schad@usace.army. mil, or manager of the Aquatic Plant Control Research Program, Christine VanZomeren (601) 634-2702, Christine.M.Vonzomeren@ usace.army.mil. 


\section{Introduction}

\section{Background}

The Times Beach site is located within the Niagara River Area of Concern (AOC) and Niagara River Important Bird Area in Buffalo, New York, immediately adjacent to the Buffalo River AOC. Constructed as a confined disposal facility by the US Army Corps of Engineers (USACE) Buffalo District in 1971, the site was closed in 1976 after partial filling at the request of the Ornithological Society of Buffalo (Simmers and Lee 1997). The site is separated from Lake Erie by a rock berm and is composed of open water, emergent marsh, forested wetlands, and upland habitat (Figure 1). Eighteen hectares of the site are classified by the New York State Department of Environmental Conservation (NYSDEC) as a wetland BU-3 (Class I wetland); the remainder of the site consists of the NYSDECregulated $30 \mathrm{~m}^{1}$ wide adjacent area, primarily uplands.

By 2011, several invasive species dominated portions of the site, including phragmites (Phragmites australis [Cav.] Trin. Ex Steud.), Japanese knotweed (Fallopia japonica [Houtt.] Ronse Decr.), common buckthorn (Rhamnus cathartica L.), and mugwort (Artemisia vulgaris L.). Phragmites occurred as the predominant invasive species across most wetland habitats but proved particularly problematic in the emergent marsh (about 5.7 ha), where it occurred in monotypic stands in some places. Other invasive species listed above occurred in colonies scattered within higher elevation areas. This special report focuses on efforts applied to the phragmites-infested marsh and resultant changes in the vegetation community in response to phragmites control.

\section{Objective}

This work evaluated vegetation community response to mechanical cutting and herbicide applications made over a five-year period for controlling invasive phragmites at Times Beach, a $22.5 \mathrm{ha}^{2}$ nature preserve located in

\footnotetext{
${ }^{1}$ For a full list of the spelled-out forms of the units of measure used in this document, please refer to US Government Publishing Office Style Manual, 31st ed. (Washington, DC: US Government Publishing Office, 2016), 248-52, https://www.govinfo.gov/content/pkg/GPO-STYLEMANUAL2016/pdf/GPO-STYLEMANUAL-2016.pdf.
} 
Buffalo, New York. The work sought to replace the monotypic stands of phragmites with a more diverse assemblage of plants to improve ecosystem function.

\section{Approach}

In early 2012, the US Army Engineer Research and Development Center (ERDC), in collaboration with the USACE-Buffalo District and Ecology and Environment (E\&E), developed a management and restoration plan to serve as a demonstration project for improving ecosystem function, which included removal of phragmites and other selected invasive species in combination with efforts to promote beneficial plant growth. The plan began in October 2012 with funding from the US Environmental Protection Agency's (EPA) Great Lakes Restoration Initiative (GLRI). The project was slated for 2012-2016 (Years 1-5); funds were secured for an additional year (2017) of management, but those results are not included in this report. 
Figure 1. Times Beach (bordered in white) is a 22.7-hectare confined disposal facility located near the mouth of the Buffalo River in Buffalo, New York. (Photo credit: Google Earth)

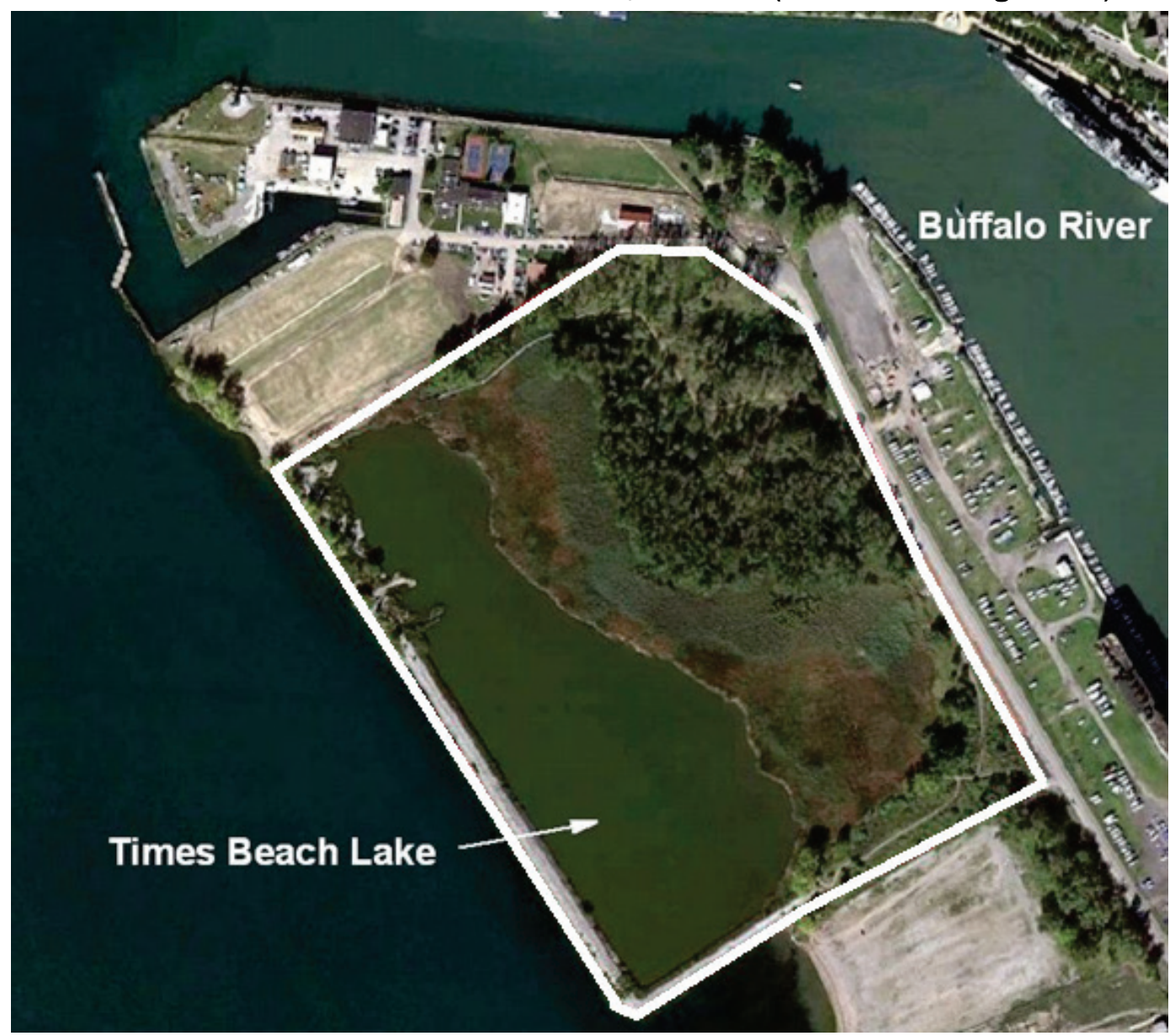

Phragmites is a tall (up to $4 \mathrm{~m}$ ), warm-season perennial grass occurring throughout the continental United States (USDA Plants Database 2018). At least 13 haplotypes have been identified in North America, 11 of which are considered nonaggressive, native varieties (Saltonstall 2002). One or more haplotypes, however, have been traced to Europe, and they are regarded as the sources of non-native, problematic infestations occurring along the Atlantic Coast, Mississippi Delta, and Great Lakes region (Meyerson and Cronin 2013; Saltonstall 2002; Chambers, Meyerson, and Saltonstall 1999; Kay 1995). Phragmites spreads by seeds, stolons, and rhizomes and is found in a variety of habitats, including freshwater wetlands (Cross and Fleming 1989; Marks, Lapin, and Randall 1994; Blossey and McCauley 2000). It also occurs commonly in areas where dredge material has been spread (Derr 2008), such as Times Beach.

Phragmites typically grows in dense stands, which may have a negative effect on many wetland plant species through competitive interactions, 
including excessive shading and crowding (Marks, Lapin, and Randall 1994; Blossey and McCauley 2000). Because of aggressive growth and impacts on wetlands, phragmites has become a major targeted invasive species in the United States, where more than $\$ 4.6$ million was spent on phragmites control from 2005 to 2009 (Martin and Blossey 2013). Most of this spending reflected herbicide use for controlling phragmites, but other management techniques, such as cutting and burning, are also applied, alone or in conjunction with others.

A seed bank survey was conducted in 2011 in the emergent marsh area of Times Beach in preliminary work associated with, but prior to, initiation of the demonstration (Appendix A, Judy F. Shearer). Evaluating the seed bank served two purposes: identifying the presence of invasive and native species that might influence outcomes of proposed management and restoration actions and providing information on whether treatment strategies were favorable or unfavorable to the overall management and restoration plan. The seed bank survey identified 42 species of plants, including 23 native species and 19 introduced taxa. Because not all introduced species become problematic, some introduced species (16 of those identified) were deemed acceptable as members of the plant community at Times Beach. Three species were either targeted for control (phragmites) or were slated for management only if monitoring data indicated rapid, aggressive expansion over time (garlic mustard, Alliaria petiole; purple loosestrife, Lythrum salicaria).

In this demonstration, we applied annual mechanical and herbicide pressures against phragmites over a five-year period, with treatment differences in herbicides made in the second and third years. During the same time, we monitored vegetation to evaluate community changes in response to management application. 


\section{Materials and Methods}

The 5.7 ha emergent wetland area at Times Beach was divided into three treatment areas (TAs) to permit efficacy evaluation of three different herbicide treatments conducted in Years 2 and 3 of the demonstration (2013 and 2014). TA 1, 2, and 3 were 1.9, 2.1, and 1.7 ha, respectively. Other management activities occurring at the site were similar between TAs, including mowing and thatch removal from Years 2-4 and follow-up herbicide treatments in Years 4 and 5.

Figure 2. The 5.7 ha emergent marsh portion of Times Beach was divided into three treatment areas (TAs) for evaluation of different herbicide applications during two years of the five-year project. (Photo credit: Google Earth)

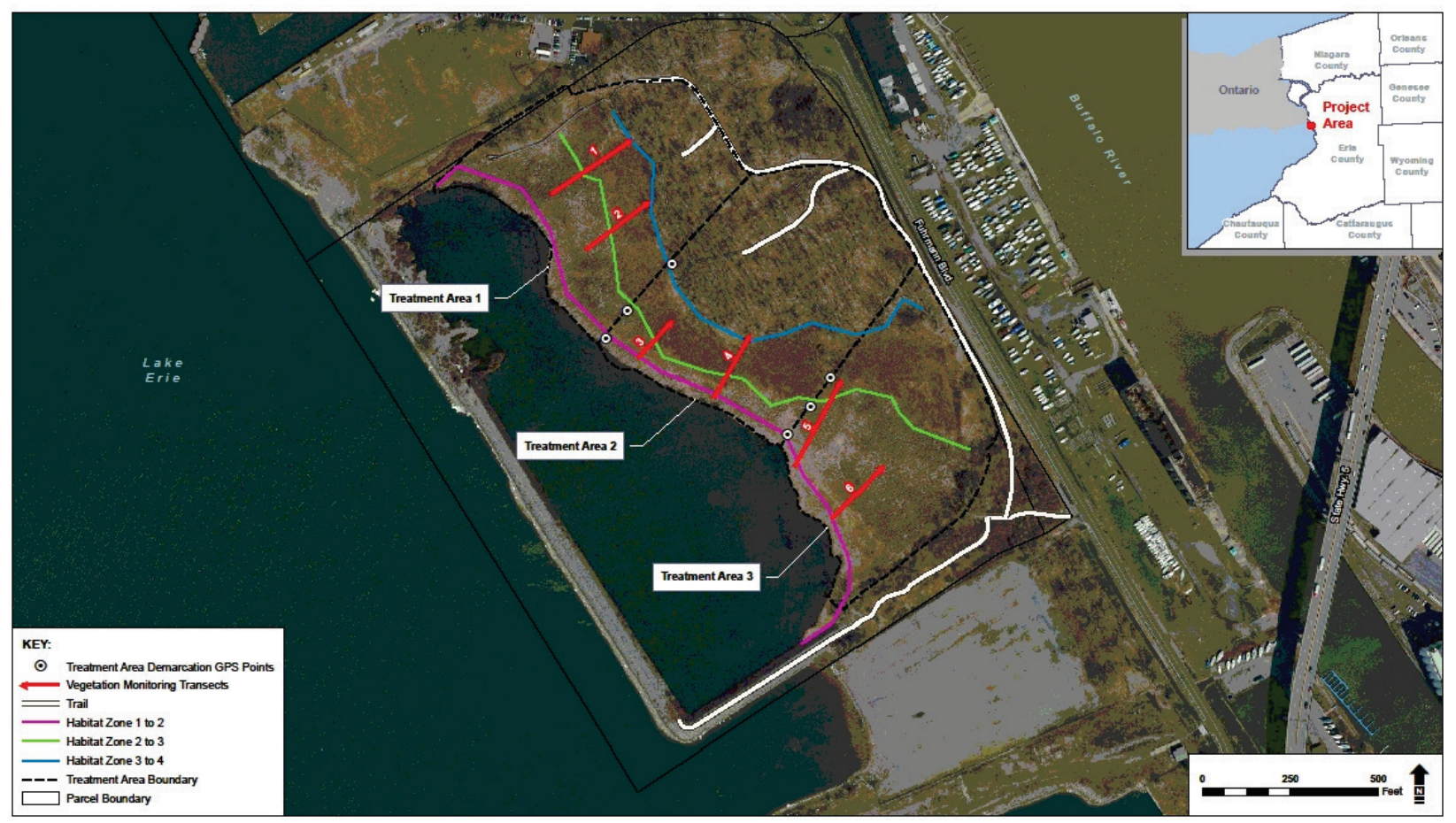

\section{Mechanical control}

Mowing and thatch removal were included across the TAs to improve herbicide coverage during application and to increase opportunities for seed bank recovery at the site. The three TAs were mowed using an amphibious vehicle equipped with a tow behind mower in Years 1-3 (November 2012, 2013, and 2014). Mowing was deemed unnecessary in Years 4 and 5, with limited hand cutting occurring in Year 4. Following mowing, loaders and haul trucks removed cut material (thatch) from the site for offsite disposal. 


\section{Herbicide applications}

Table 1 provides a schedule of herbicide applications at Times Beach. Per the NYSDEC, no management activities took place during the spring migratory and breeding bird seasons (April 1-August 31), which restricted vegetation management activities to later in the growing season in Years 1-3. A permit modification was acquired from NYSDEC in 2015 that allowed for late-spring applications in Years 4 and 5 .

Table 1. Herbicide applications at Times Beach, New York.

\begin{tabular}{|c|c|c|c|c|c|}
\hline Year & Month & TA1 & TA2 & TA3 & Comments \\
\hline 1 & -- & none & none & none & \\
\hline 2 & September & glyphosate (2\%) & $\begin{array}{l}\text { glyphosate \& } \\
\text { imazamox (1\% } \\
\& 2 \%)\end{array}$ & $\begin{array}{l}\text { imazamox } \\
(4 \%)\end{array}$ & Site-wide foliar spray \\
\hline 3 & $\begin{array}{l}\text { September and } \\
\text { October }\end{array}$ & glyphosate (2\%) & $\begin{array}{l}\text { glyphosate \& } \\
\text { imazamox (1\% } \\
\& 2 \%)\end{array}$ & $\begin{array}{l}\text { imazamox } \\
(4 \%)\end{array}$ & $\begin{array}{l}\text { Spot treatments foliar } \\
\text { spray }\end{array}$ \\
\hline 4 & $\begin{array}{l}\text { September and } \\
\text { October }\end{array}$ & glyphosate (2\%) & glyphosate (2\%) & $\begin{array}{l}\text { glyphosate } \\
(2 \%)\end{array}$ & $\begin{array}{l}\text { Spot treatments foliar } \\
\text { spray }\end{array}$ \\
\hline 5 & July and October & glyphosate (2\%) & glyphosate (2\%) & $\begin{array}{l}\text { glyphosate } \\
(2 \%)\end{array}$ & $\begin{array}{l}\text { Spot treatments foliar } \\
\text { spray }\end{array}$ \\
\hline
\end{tabular}

In the fall of Year 2, following the first late-fall mow- and thatch-removal activities conducted in Year 1, initial herbicide applications were made. TA1 was treated with $2 \%$ glyphosate and $0.5 \%$ v.v. nonionic surfactant; TA2 was treated with a combination of $1 \%$ glyphosate plus $2 \%$ imazamox and $1 \%$ v.v. methylated seed oil; TA3 was treated with $4 \%$ imazamox and $1 \%$ v.v. methylated seed oil. Treatments were made by foliar application and applied using an amphibious vehicle equipped with a spray tower and boom. Because regrowth of phragmites following mowing and thatch removal was dense and widespread, large portions of the site required treatment, with exceptions near the open-water area, where cattails were avoided when possible by selectively spraying (spot-treating) phragmites colonies. A second herbicide application was made in Year 3 (following a second mow and thatch removal in late fall Year 2) on the same three TAs using the methods described above, but this application required only spot treatments of recovering patches of phragmites. Estimates indicating substantial phragmites control by Year 4 (Glomski et al. 2016) resulted in the project shifting to maintenance management of phragmites using $2 \%$ glyphosate with surfactant in all TAs in Years 4 and 5 . 


\section{Vegetation community monitoring}

Two permanent transects were established within each TA for vegetation community monitoring (Figure 2 and Table 2). Transects were set between the forest and emergent marsh edge and the shoreline of the open-water areas. Survey techniques were similar to Daubenmire (1959), which required field identification of plants to the lowest taxon possible and included estimates of unvegetated (bare or debris-covered) ground. Mean percent cover of all species was determined along each transect using line intercept techniques. A $1 \mathrm{~m} \times 0.5 \mathrm{~m}$ quadrat was placed at $3 \mathrm{~m}$ intervals along each transect (alternating between the right and left sides) and percent cover of each species was recorded. The first (adjacent to forest) and last (adjacent to shoreline) $3 \mathrm{~m}$ of each transect was not evaluated. Numbers of quadrats along each transect varied from year to year, depending on water levels and position of each year's shoreline. Plants within the quadrat were identified to the lowest taxon possible, with percent cover of each visually estimated using the following cover class values: $1-5 \%, 6-25 \%, 26-50 \%, 51-75 \%, 76-95 \%$, and $96-100 \%$. The mean value for each cover class was used for importance value calculation and statistical analysis (that is, $2.5,15,37.5,62.5,85$, and 97.5).

Table 2. Transects used for vegetation community monitoring at Times Beach 2012-2016.

\begin{tabular}{|c|c|c|c|c|}
\hline Transect \# & TA & $\begin{array}{l}\text { Maximum } \\
\text { length }(m)\end{array}$ & Minimum plots & Maximum plots \\
\hline 1 & \multirow{2}{*}{1} & 132 & 21 & 44 \\
\hline 2 & & 120 & 26 & 40 \\
\hline 3 & \multirow{2}{*}{2} & 69 & 12 & 23 \\
\hline 4 & & 84 & 13 & 28 \\
\hline 5 & \multirow{2}{*}{3} & 165 & 30 & 55 \\
\hline 6 & & 147 & 41 & 49 \\
\hline
\end{tabular}

A baseline vegetation survey was conducted in Year 1 (August 2012), prior to mowing, thatch removal, and herbicide applications. Subsequent surveys were conducted in June of Years 2-5.

\section{Data analysis}

Transect survey data from within each TA were used to calculate three vegetation community structure dependent variables: (1) relative cover for each taxon (\% total coverage of transect quadrats per transect, relative 
cover [RC]); (2) relative frequency (number of quadrats in which a taxon was identified, Relative Frequencies [RF]); and (3) importance values (sum of RC and RF, 200 maximum score). Each taxon was then assigned to one of seven vegetation groups for community structure analysis: natives (Group 1); acceptable nonnatives (Group 2); potential problem nonnatives (Group 3); purple loosestrife (Group 4); phragmites (Group 5); cattails (Group 6); and bare or debris (Group 7), with sums of taxa within a group used to calculate group RC, RF, and importance values (IV).

Vegetation community structure (RC, RF, and IV) along each transect (herein referred to as sampling site) in each TA in each sampling year was classified and ordinated with cluster analysis and nonmetric multidimensional scaling (NMDS) to assess spatial similarities and temporal trends. Annual sampling data (five years) and herbicide treatment (three levels: glyphosate, glyphosate + imazamox, and imazamox) were used to distinguish the 15 total sampling sites for similarity analysis. For all meaned transect vegetation community structure data, classification was done with cluster analysis using a Bray-Curtis similarity matrix (Jackson 1993; Clarke and Warwick 2001). Vegetation community structure data were $\log 10(x+1)$ transformed and normalized (Jackson 1993; Heino 2000). Community groups were then delineated by ordination analysis using nonmetric multidimensional scaling (NMDS) (Kruskal 1964; Kenkel and Orloci 1986; Shin and Fong 1999). Cluster similarity dendrograms, NMDS delineations with resemblance levels, and NMDS native and phragmites bubble plots are all given. In the results and discussion section for sampling site classification and ordination, sites are coded as: herbicide-three levels (glyphosate alone, glyphosate and imazamox, and imazamox alone); labeled $G, G I$, and $I$; sampling date-five levels (Years 1,2,3,4,5); labeled 1, 2, 3, 4, 5. All multivariate analyses were done using Primer 7 (Primer-E, Auckland, New Zealand). 


\section{Results and Discussion}

During the five-year demonstration, this study identified 84 plant taxa along transects in the emergent marsh (Appendix B). Of these, 61.9\% (52) were grouped as native; 30.9\% (26) acceptable nonnative; $2.3 \%$ (2) potential problem nonnative; and $1.1 \%$ each for purple loosestrife, phragmites, and cattails. While mean numbers of taxa observed per transect varied from year to year, numbers were lowest in Year 1, then steadily increased in subsequent years, nearly quadrupling by Year 5 (Table 3).

Table 3. Number of plant taxa identified along transects at Times Beach, New York, in Years 1-5 (2012-2015).

\begin{tabular}{|l|l|l|l|l|l|l|}
\hline Transect \# & TA & Year 1 & Year 2 & Year 3 & Year 4 & Year 5 \\
\hline Transect 1 & \multirow{2}{*}{ 1 (glyphosate) } & 10 & 14 & 21 & 27 & 23 \\
\cline { 4 - 7 } Transect 2 & & 6 & 13 & 16 & 29 & 24 \\
\hline Transect 3 & \multirow{2}{*}{$\begin{array}{l}\text { (glyphosate \& } \\
\text { imazamox) }\end{array}$} & 4 & 12 & 15 & 21 & 15 \\
\cline { 1 - 6 } Transect 4 & 5 & 12 & 13 & 20 & 18 \\
\hline Transect 5 & \multirow{2}{*}{ 3 (imazamox) } & 5 & 11 & 13 & 23 & 19 \\
\cline { 3 - 8 } Transect 6 & 3 & 9 & 14 & 20 & 32 \\
\hline mean & & 5.5 & 11.8 & 15.3 & 23.3 & 21.8 \\
\hline
\end{tabular}

Of the taxa that were found along transects, 26 represented $62 \%$ of those identified in the seed bank analysis conducted in 2011 (Appendices A and B). Seed bank taxa occurred in all groups (excluding bare or debris): 16 were grouped as native, 6 as acceptable nonnative, and 1 each in the other groups (potential problem nonnative, purple loosestrife, phragmites, and cattails). These occurrences indicate seed bank persistence at the site.

Cluster analysis and NMDS based on Bray-Curtis similarity matrices of the seven vegetation groups' $\mathrm{RC}$ identified 5 ( $>80 \%$ ) similar location groupings of the 15 sampling sites (mean transect data for three TAs over five years; Figures 3 and 4). These RC resemblance groupings showed dissimilarities in vegetation community structure over time, highlighted by declines in phragmites. Results between the three TAs were similar in terms of relative cover, indicating no differences in herbicide efficacy, confirming the conclusions of Glomski et al. (2016) that no differences in efficacy between glyphosate, imazamox, and the combination of the two exist. The RC of other groups were similar to one another across TAs, increasing or remaining stable between Years $1-5$, with the exception of 
bare or debris, which decreased (Appendix C). Appendix D gives the NMDS ordination of sampling sites based on vegetation relative cover with bubble plot overlay for all groups.

Figure 3. Dendrogram of 15 sampling sites (three TAs times five years) based on cluster analysis of vegetation relative cover (Bray-Curtis) similarity at Times Beach, New York (20122016).

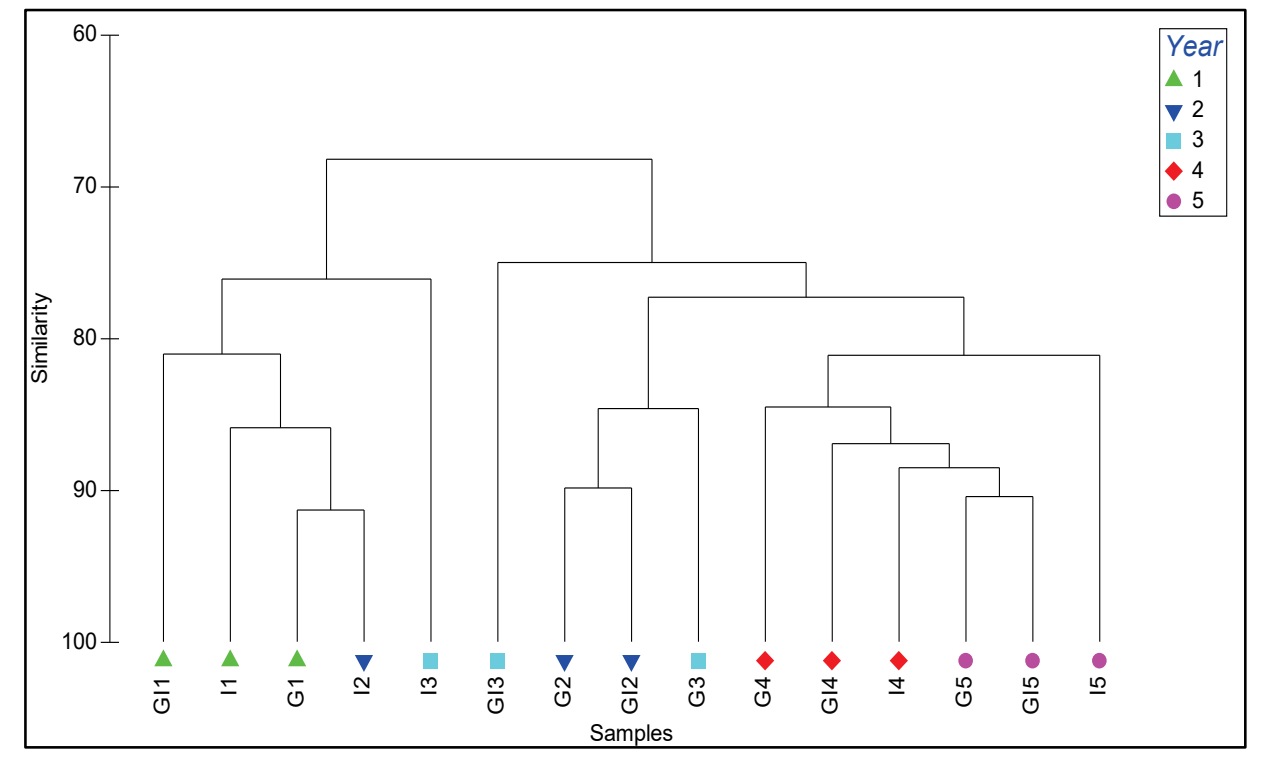

Figure 4. Relative cover of 15 sampling sites (TAs $\times$ year) at Times Beach, New York, (20122016) on first two dimensions from nonmetric multidimensional scaling (NMDS). Bray-Curtis similarity of 70,80 , and $90 \%$ resemblance similarity levels are given.

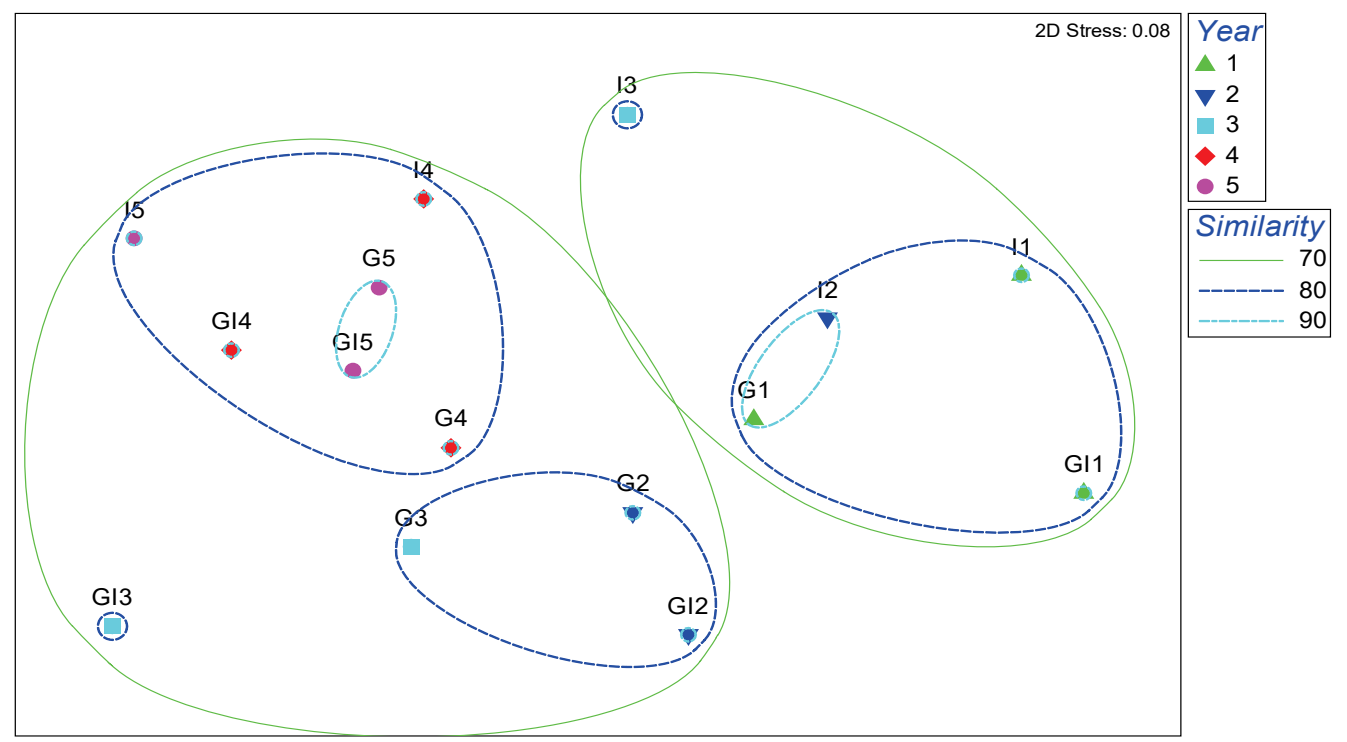

Similar trends were seen in RF over time. Analysis identified 7 (>90\%) similar location groupings of the 15 sampling sites (Figures 5 and 6). 
Resemblance groupings of RF indicated dissimilarities between sampling years, with results between TAs similar to one another (Figure 6).

Frequency of phragmites decreased over the study period, albeit to a lesser degree than that seen in RC, while other groups increased or remained stable over time.

Figure 5. Dendrogram of 15 sampling sites (three TAs times five years) based on cluster analysis of vegetation relative frequency (Bray-Curtis) similarity at Times Beach, New York (2012-2016).

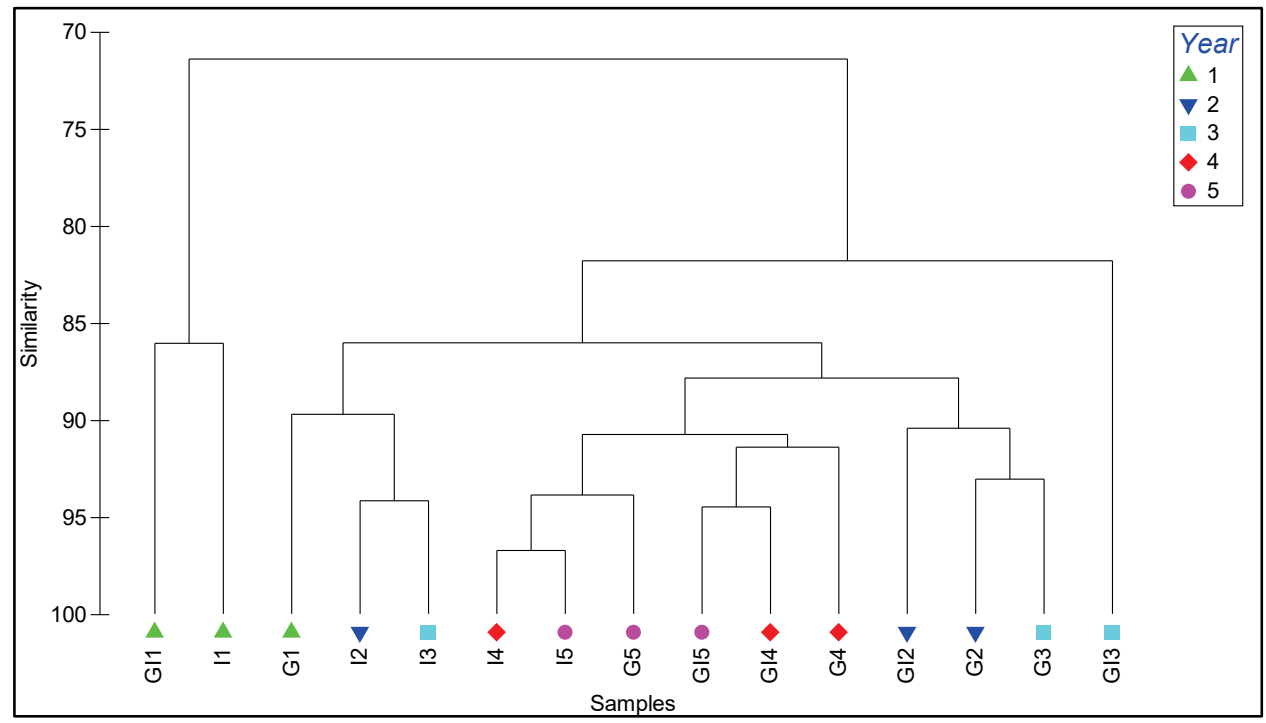

Figure 6. Relative frequency of 15 sampling sites (three TAs times five years) at Times Beach, New York, (2012-2016) on first two dimensions from NMDS. Bray-Curtis similarity of 70, 80, and $90 \%$ resemblance similarity levels are given.

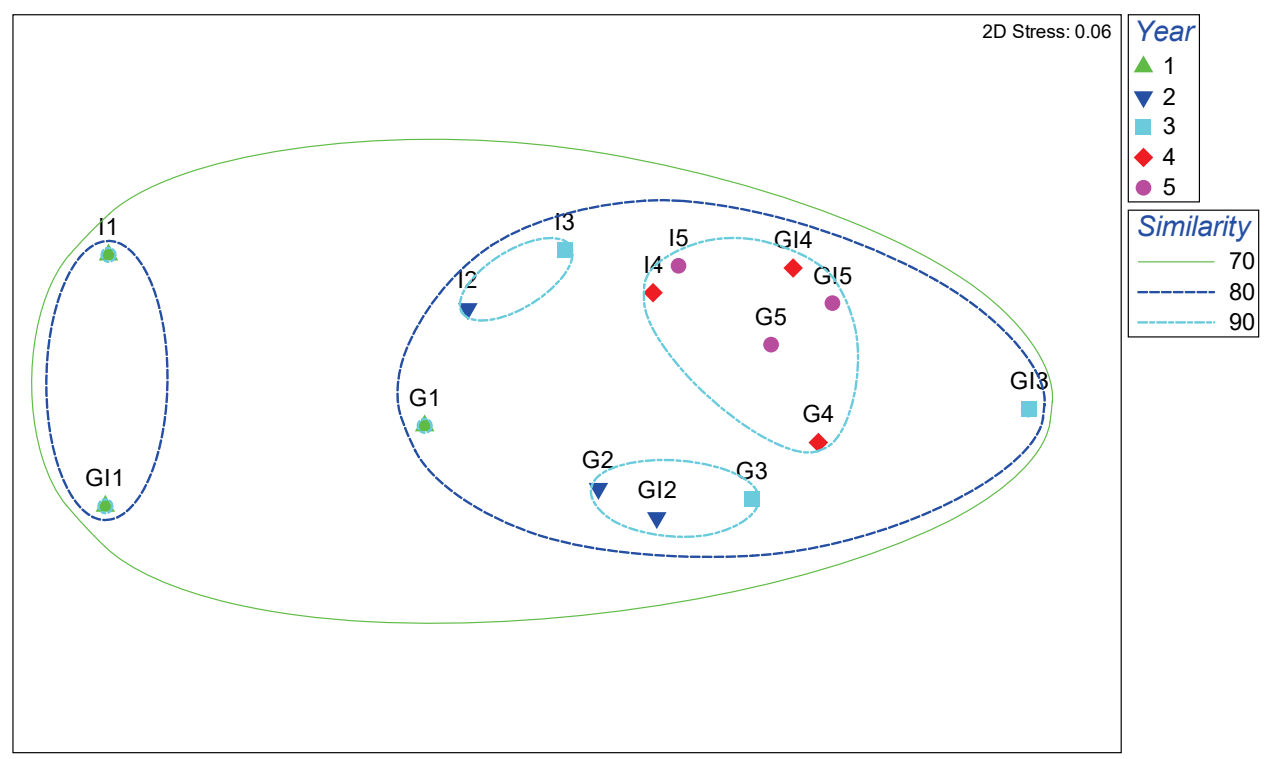


Importance values (combined RC and RF) followed a similar, but stronger, trend. Analysis identified nine ( $>90 \%$ ) similar location grouping of the 15 sampling sites (Figures 7 and 8). As in RC and RF, resemblance groupings indicated dissimilarities between sampling years due to vegetation's community structure change, primarily through decreases in phragmites and bare or debris importance and increases in other groups.

Figure 7. Dendrogram of 15 sampling sites (three TAs times five years) based on cluster analysis of vegetation importance value (Bray-Curtis) similarity at Times Beach, New York (2012-2016).

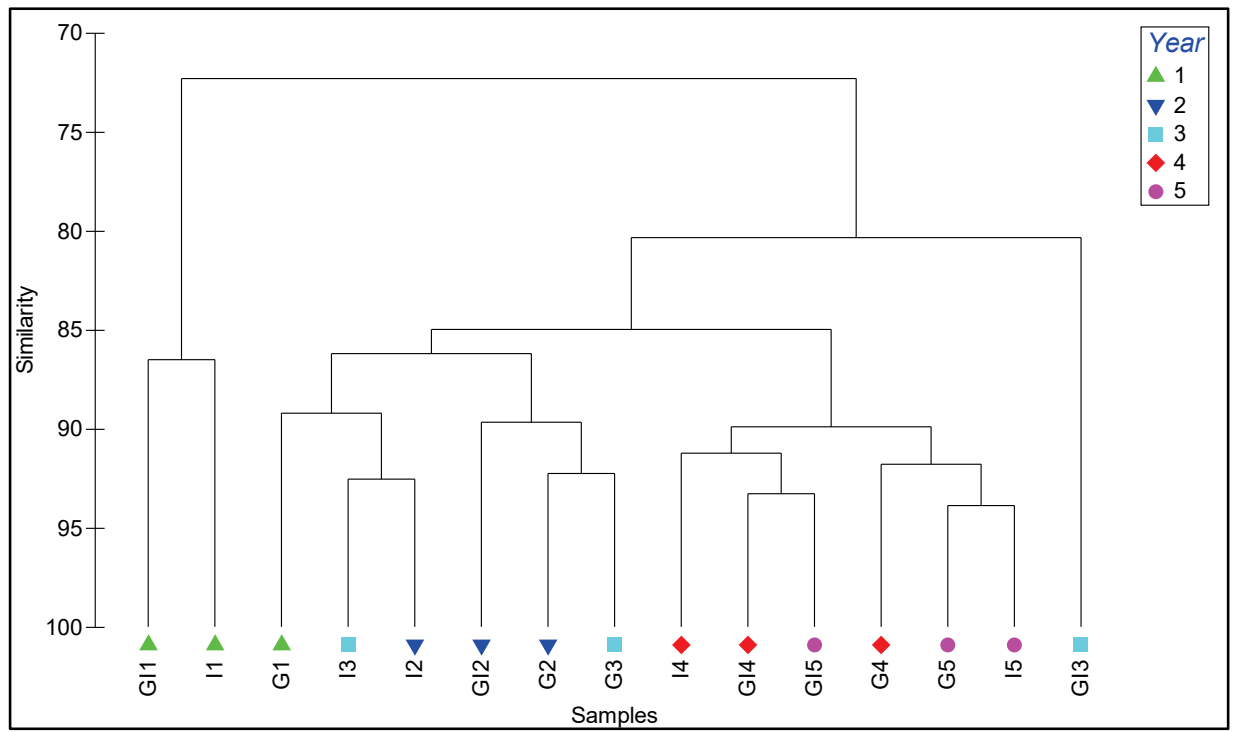

Figure 8. Importance Values of 15 sampling sites (three TAs times five years) on first two dimensions from NMDS. Bray-Curtis similarity of 70,80 , and $90 \%$ resemblance similarity levels are given.

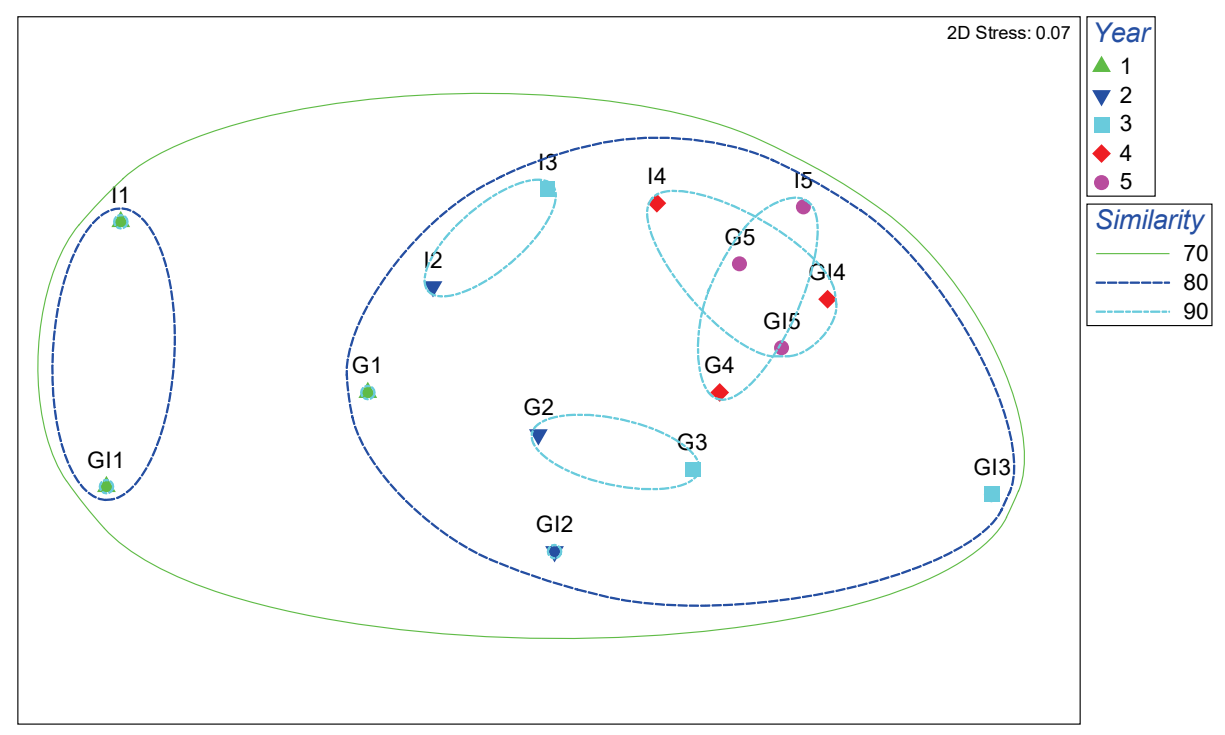


Although unmanaged control plots were not used in the project, the results seem to suggest that management targeted at phragmites was the main effector of vegetation community changes, with herbicides having the greatest impact. Year 1 mowing and thatch removal moderately reduced phragmites across the three TAs in Year 2, from an average of 49.9 IV to $35.2 \mathrm{IV}$, but the greatest phragmites decline was recorded in Year 3, following Year 2 herbicide applications (from an average of 35.2 IV to 3.9 IV; Figure 9). Continued mowing and thatch removal coupled with herbicide suppression in subsequent years resulted in an average of $5.5 \mathrm{IV}$ (and corresponding 1.2\% RC, Appendix C) by Year 5 .

Figure 9. Importance values (IV) for seven groups of vegetation identified along transects over a five-year period at Times Beach, New York. Year 1 was baseline.

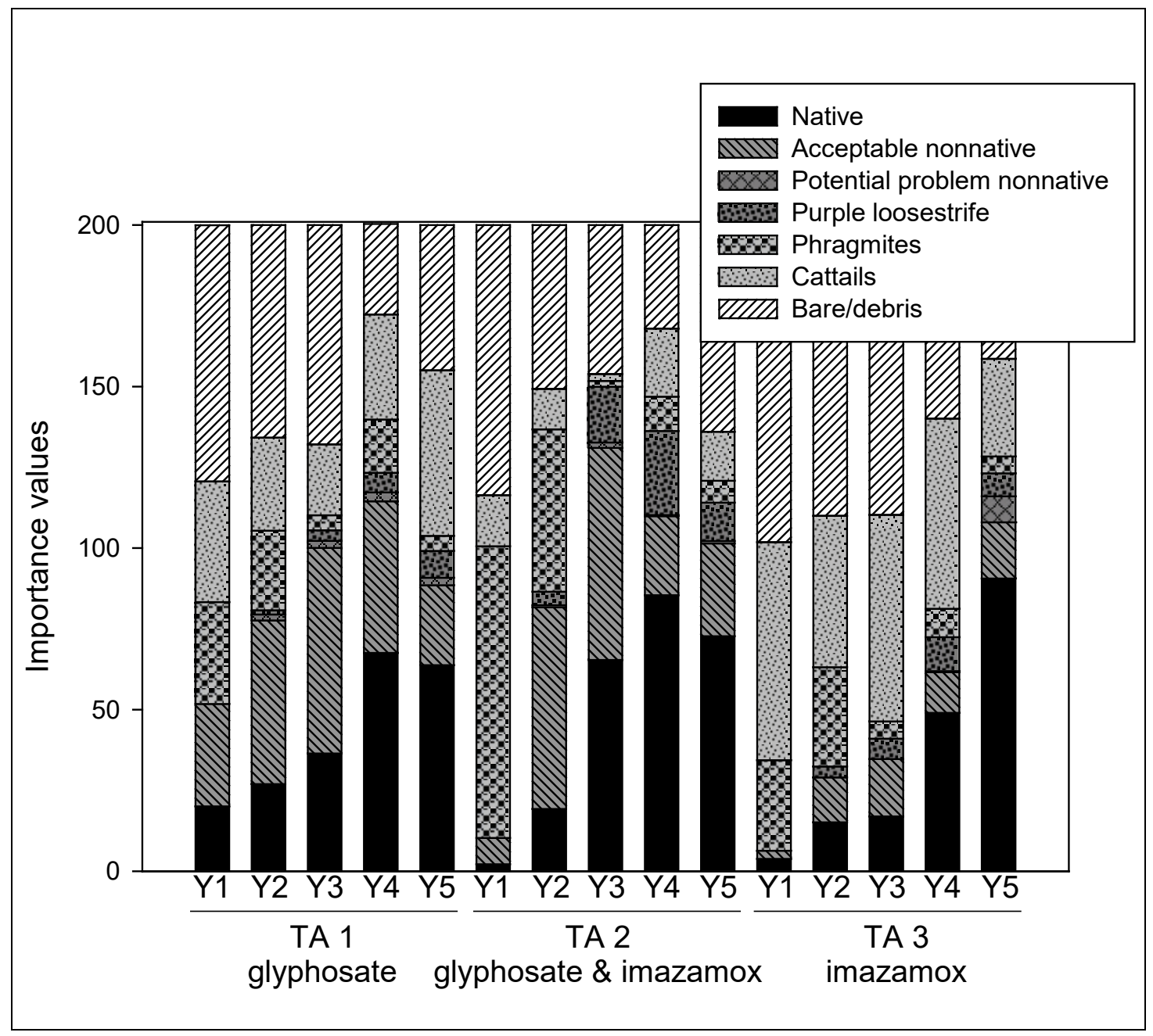

Dense stands of phragmites are reported to suppress seed germination, and their removal can release limits on light, temperature, nutrients, and other factors required for the germination and growth of many plant 
species (Blossey and McCauley 2000). This change appeared to have occurred at Times Beach concurrently with reduction of phragmites at Times Beach. Figure 9 shows general trends in IV for groups of vegetation assigned in the demonstration. Bare or debris IV, along with phragmites, declined between Year 1 and Year 5, while other groups either increased (most notably native) or remained stable (most notably cattails). Project goals were met through replacement of most phragmites originally present with native and acceptable non-native plants (Figure 10). However, several groups, including purple loosestrife and potential problematic nonnatives, also increased, indicating that long-term management of the site may require not only continued suppression of phragmites but other invasive species as well.

Figure 10. Times Beach phragmites infestation in fall 2012 (top), prior to management, and in fall 2017 (bottom) following five years of management. (Photo credit: Gary Dick)

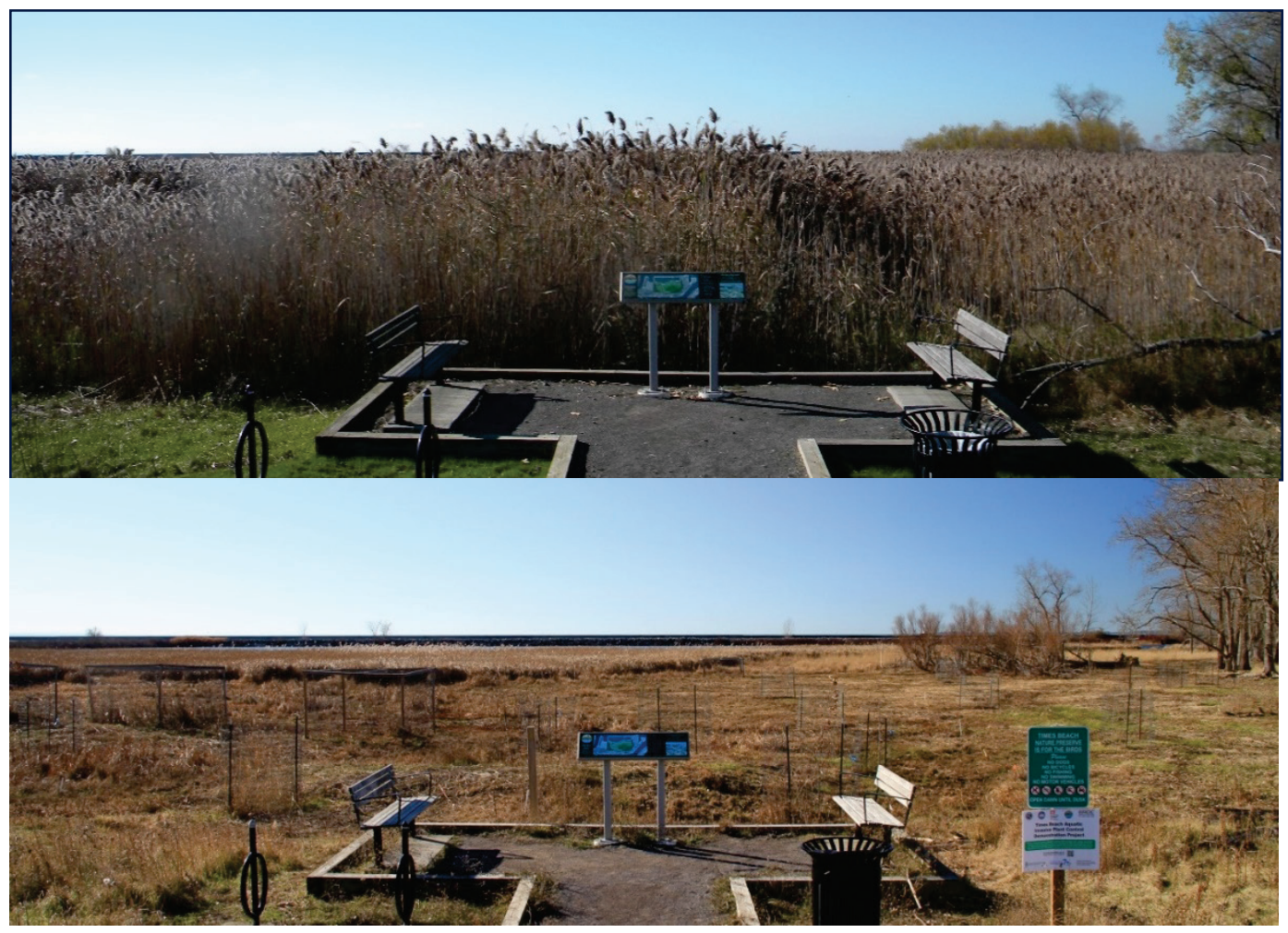




\section{References}

Blossey, B., and J. McCauley. 2000. A plan for developing biological control of Phragmites australis in North America. Wetland J. 12:23-28.

Chambers, R. M., L. A. Meyerson, and K. Saltonstall. 1999. Expansion of Phragmites australis into tidal wetlands of North America. Aquat. Bot. 64:261-273.

Clarke K. R. and R. M. Warwick. 2001. Change in marine communities: an approach to statistical analysis and interpretation. 2nd ed. Primer-E: Plymouth.

Cross, D. H., and K. L. Fleming. 1989. Control of phragmites or common reed. US Fish and Wildlife Leaflet 13.4.12. Washington, D.C.: US Department of the Interior, Fish and Wildlife Service. 5 pp.

Daubenmire, R. 1959. A canopy-coverage method of vegetational analysis. Northwest Sci. 33(1):43-64.

Derr, J. F. 2008. Common reed (Phragmites australis) response to mowing and herbicide application. Invasive Plant Sci. Manage. 1:12-16.

Glomski, L. M., J. F. Shearer, G. O. Dick, K. Erickson, and P. Fuhrmann. 2016. Phragmites Management at Times Beach, Buffalo, NY. APCRP Technical Notes Collection. ERDC/TN APCRP-CC-20. Vicksburg, MS: US Army Engineer Research and Development Center. $h$ ttp://ed.erdc.usace.army.mil/aqual

Heino, J. 2000. "Lentic macroinvertebrate assemblage structure along gradients in spatial heterogeneity, habitat size and water chemistry." Hydrobiologia 418:229242.

Jackson, D. 1993. "Multivariate analysis of benthic invertebrate communities: the implication of choosing particular data standardizations, measures of association, and ordination methods." Hydrobiologia 268:9-26.

Kay, S. 1995. Efficacy of wipe-on applications of glyphosate and imazapyr on common reed in aquatic sites. J. Aquat. Plant Manage. 33:25-26.

Kenkel, N. C., and L. Orloci L. 1986. "Applying metric and nonmetric multidimensional scaling to ecological studies: some new results." Ecology 67:919-928.

Kruskal, J. B. 1964. "Multidimensional scaling by optimizing goodness of fit to a nonmetric hypothesis." Psychometrika 29:1-27.

Marks, M., B. Lapin, and J. Randall. 1994. Phragmites australis (P. communis): Threats, management and monitoring. Nat. Areas J. 14:285-294.

Martin, L. J., and B. Blossey. 2013. The runaway weed: costs and failures of Phragmites australis management in the USA. Estuar. Coast. 36:626-632.

Meyerson, L. A., and J. T. Cronin. 2013. Biol. Invasions (2013) 15: 2605. https://doi.org/10.1007/s10530-013-0491-2 
Saltonstall, K. 2002. Cryptic invasion by a non-native genotype of the common reed, Phragmites australis, into North America. PNAS 99:2445-2449.

Shin, P. K. S., and K. Y. S. Fong. 1999. "Multiple discriminant analysis of marine sediment data." Marine Pollution Bulletin 39:285-294.

Simmers, J. W., and C. R. Lee. 1997. Long-term evaluation of Times Beach Confined Disposal Facility, Buffalo, New York; An update. Environmental Effects of Dredging Technical Notes EEDP-02-21. US Army Engineer Waterways Experiment Station, Vicksburg, MS. http://el.erdc.usace.army.mil/dots/pdfs/eedp02-21.pdf

USDA Plant Database. 2018. https://plants.usda.gov/core/profile?symbol=PHAU7. Accessed March 2, 2018. 


\section{Appendix A: Times Beach Seed Bank Species Data Collected in 2011}

\begin{tabular}{|c|c|c|}
\hline Scientific Name & Common Name & $\begin{array}{l}\text { Native }(\mathrm{N}) \text { or } \\
\text { Introduced (I) }\end{array}$ \\
\hline $\begin{array}{l}\text { Alliaria petiolata } \\
\text { (M. Bieb.) Cavara \& Grande }\end{array}$ & Garlic mustard & I \\
\hline Althaea officinalis L. & Common marshmallow & $\mathrm{I}$ \\
\hline Barbarea vulgaris W. T. Aiton & Yellow rocket & $\mathrm{I}$ \\
\hline Carex spp. & Sedge & $\mathrm{N}$ \\
\hline Chenopodium album L. & Lambsquarters & $\mathrm{I}$ \\
\hline Chenopodium glaucum L. var. glaucum & Oakleaf goosefoot & $\mathrm{I}$ \\
\hline Cirsium arvense (L.) Scop. & Canada thistle & $\mathrm{I}$ \\
\hline Cyperus diandrus Torr & Umbrella flatsedge & $\mathrm{N}$ \\
\hline Cyperus erythrorhizos Muhl. & Redroot flatsedge & $\mathrm{N}$ \\
\hline Cyperus esculentus L. var. leptostachyus & Yellow nutsedge & I \\
\hline Cyperus strigosus L. & Straw colored flatsedge & $\mathrm{N}$ \\
\hline $\begin{array}{l}\text { Eleocharis acicularis (L. Roem and Schult. var. } \\
\text { acicularis) }\end{array}$ & Needle spikerush & $\mathrm{N}$ \\
\hline $\begin{array}{l}\text { Erechtites hieracifolia (L.) Raf. Ex DC. var. } \\
\text { hieracifolia }\end{array}$ & American burnweed & $\mathrm{N}$ \\
\hline Eupatorium perfoliatum L. & Common boneset & $\mathrm{N}$ \\
\hline Eurybia divaricate (L.) G.L. Nesom & Wood aster & $\mathrm{N}$ \\
\hline Leersia oryzoides (L.) Sw. & Rice cutgrass & $\mathrm{N}$ \\
\hline Lindernia dubia (L.) Pennell var. dubia & Yellowseed false pimpernel & $\mathrm{N}$ \\
\hline Lycopus uniflorus Michx. & Northern bugleweed & $\mathrm{N}$ \\
\hline Lythrum salicaria L. & Purple loosestrife & I \\
\hline Medicago Iupulina L. & Black medick & I \\
\hline Mentha arvensis L. & Wild mint & I \\
\hline Mimulus ringens L. var. ringens & Allegheny monkeyflower & $\mathrm{N}$ \\
\hline Panicum capillare L. ssp. capillare & Witchgrass & $\mathrm{N}$ \\
\hline Persicaria hydropiperoides (Michx.) Small & Swamp smartweed & $\mathrm{N}$ \\
\hline Persicaria lapathifolia (L.) Gray & Pale smartweed & $\mathrm{I}$ \\
\hline Phalaris arundinacea L. & Reed canarygrass & $\mathrm{N}$ \\
\hline Phragmites australis Trin. X Steud. ssp. australis & Common reed & I \\
\hline $\begin{array}{l}\text { Populus deltoides Bartram ex Marsh. ssp. } \\
\text { deltoides }\end{array}$ & Eastern cottonwood & $\mathrm{N}$ \\
\hline Portulaca oleracea L. & Common purslane & 1 \\
\hline Raphanus raphanistrum L. & Wild radish & I \\
\hline Rhus typhina L. & Staghorn sumac & $\mathrm{N}$ \\
\hline Salix nigra Marsh. & Black willow & $\mathrm{N}$ \\
\hline $\begin{array}{l}\text { Schoenoplectus tabernaemontani (C. C. Gmel.) } \\
\text { Palla }\end{array}$ & Softstem bulrush & $\mathrm{N}$ \\
\hline Solanum ptycanthum Dunal & Black nightshade & $\mathrm{I}$ \\
\hline Solidago altissima L. & Canada goldenrod & $\mathrm{N}$ \\
\hline Typha sp. & Cattail & $\mathrm{N}$ \\
\hline Urtica dioica L. ssp. dioica & Stinging nettle & I \\
\hline Verbascum blattaria L. & Moth mullein & I \\
\hline Verbascum thapsus L. & Common mullein & $\mathrm{I}$ \\
\hline Verbena bracteata Cav. Ex Log. \& Ridr & Bigbract verbena & I \\
\hline
\end{tabular}


Native (N) or

Scientific Name

Common Name

Introduced (I)

Verbena hastata L. var. hastata

Swamp verbena $\mathrm{N}$

Verbena urticifolia L.

White vervain

$\mathrm{N}$




\section{Appendix B: Vegetation Species and Groupings Identified Along Six Transects at Times Beach between 2012 and 2016}

\begin{tabular}{|c|c|c|}
\hline Scientific Name & Common Name & $\begin{array}{l}\text { Present in seed bank } \\
\text { analysis }\end{array}$ \\
\hline \multicolumn{3}{|l|}{ Group 1 (native) } \\
\hline Acer sp. & Maple & $\mathrm{N}$ \\
\hline Achillea millefolium & Common yarrow & $\mathrm{N}$ \\
\hline Alisma subcordatum & American water plantain & $\mathrm{N}$ \\
\hline Bidens sp. & Beggarticks & $\mathrm{N}$ \\
\hline Brassica sp. & Mustard & $\mathrm{N}$ \\
\hline Carex lurida & Shallow sedge & $\mathrm{N}$ \\
\hline Carex scoparia & Broom sedge & $\mathrm{N}$ \\
\hline Carex sp. & Sedge & $\mathrm{Y}$ \\
\hline Cephalanthus occidentalis & Common buttonbush & $\mathrm{N}$ \\
\hline Chenopodium sp. & Goosefoot & $\mathrm{Y}$ \\
\hline Cirsium sp. & Thistle & $\mathrm{Y}$ \\
\hline Conyza canadensis & Canadian horseweed & $\mathrm{N}$ \\
\hline Cyperus sp. & Flatsedge & $\mathrm{Y}$ \\
\hline Eleocharis obtusa & Blunt spikerush & $\mathrm{N}$ \\
\hline Eleocharis sp. & Spike rush & $\mathrm{Y}$ \\
\hline Epilobium sp. & Willow herb & $\mathrm{N}$ \\
\hline Equisetum arvense & Field horsetail & $\mathrm{N}$ \\
\hline Equisetum scirpoides & Dwarf scouring rush & $\mathrm{N}$ \\
\hline Equisetum sp. & Horsetail & $\mathrm{N}$ \\
\hline Galium aparine & Bedstraw & $\mathrm{N}$ \\
\hline Impatiens capensis & Jewelweed & $\mathrm{N}$ \\
\hline Juncus canadensis & Canadian rush & $\mathrm{N}$ \\
\hline Juncus effusus & Common rush & $\mathrm{N}$ \\
\hline Juncus sp. & Rush & $\mathrm{N}$ \\
\hline Juncus tenuis & Poverty rush & $\mathrm{N}$ \\
\hline Leersia oryzoides & Rice cut grass & $\mathrm{Y}$ \\
\hline Lemna minor & Duckweed & $\mathrm{N}$ \\
\hline Lindernia dubia & Yellowseed false pimpernel & $\mathrm{Y}$ \\
\hline Lycopus uniflorus & Northern bugleweed & $\mathrm{Y}$ \\
\hline Lycopus virginicus & Virginia bugleweed & $\mathrm{N}$ \\
\hline Lysimachia sp. & Loosestrife & $\mathrm{N}$ \\
\hline Morella pensylvanica & Northern bayberry & $\mathrm{N}$ \\
\hline Oxalis sp. & Wood sorrel & $\mathrm{N}$ \\
\hline Parthenocissus quinquefolia & Poison ivy & $\mathrm{N}$ \\
\hline Penstemon pallidus & Eastern white beardtongue & $\mathrm{N}$ \\
\hline
\end{tabular}




\begin{tabular}{|c|c|c|}
\hline Scientific Name & Common Name & $\begin{array}{l}\text { Present in seed bank } \\
\text { analysis }\end{array}$ \\
\hline Persicaria hydropiperoides & Swamp smartweed & $\mathrm{Y}$ \\
\hline Persicaria lapathifolia & Curlytop knotweed & Y \\
\hline Persicaria spp. 2 & Smartweed/knotweed & $\mathrm{N}$ \\
\hline Phalaris arundinacea & Reed canarygrass & $Y$ \\
\hline Populus deltoides & Eastern cottonwood & $\mathrm{Y}$ \\
\hline Potentilla sp. & Cinquefoil & $\mathrm{N}$ \\
\hline Salix interior & Sandbar willow & $\mathrm{Y}$ \\
\hline Schoenoplectus sp. & Bulrush & $\mathrm{N}$ \\
\hline Schoenoplectus americanus & Chairmaker's bulrush & $\mathrm{N}$ \\
\hline Schoenoplectus pungens & Common threesquare & $\mathrm{N}$ \\
\hline Schoenoplectus tabernaemontani & Softstem bulrush & $\mathrm{Y}$ \\
\hline Scirpus atrovirens & Green bulrush & $\mathrm{N}$ \\
\hline Scirpus sp. & Bulrush & $\mathrm{N}$ \\
\hline Scutellaria sp. & Skullcap & $\mathrm{N}$ \\
\hline Solidago sp. & Goldenrod & $\mathrm{Y}$ \\
\hline Verbena hastata & Blue vervain & $\mathrm{Y}$ \\
\hline Vernonia fasciculata & Prairie ironweed & $\mathrm{N}$ \\
\hline
\end{tabular}

\section{Group 2 (acceptable nonnative)}

\begin{tabular}{|l|l|c|}
\hline Allium sativum & Garlic & $\mathrm{N}$ \\
\hline Barbarea vulgaris & Common winter cress & $\mathrm{Y}$ \\
\hline Brassica nigra & Black mustard & $\mathrm{N}$ \\
\hline Capsella bursa-pastoris & Shepherd's purse & $\mathrm{Y}$ \\
\hline Cirsium arvense & Canada thistle & $\mathrm{Y}$ \\
\hline Cyperus esculentus & Yellow nutsedge & $\mathrm{N}$ \\
\hline Daucus carota & Queen Anne's lace & $\mathrm{N}$ \\
\hline Echinochloa crus-galli & Barnyard grass & $\mathrm{N}$ \\
\hline Epilobium hirsutum & Codlins and cream & $\mathrm{N}$ \\
\hline Hypericum perforatum & Common St. John's wort & $\mathrm{N}$ \\
\hline Lactuca serriola & Prickly lettuce & $\mathrm{N}$ \\
\hline Linaria vulgaris & Yellow toadflax & $\mathrm{N}$ \\
\hline Lolium perenne & Perennial ryegrass & $\mathrm{N}$ \\
\hline Melilotus officinalis & Sweetclover & $\mathrm{Y}$ \\
\hline Mentha arvensis & Wild mint & $\mathrm{N}$ \\
\hline Nepeta cataria & Catnip & $\mathrm{Y}$ \\
\hline Raphanus raphanistrum & Wild radish & $\mathrm{N}$ \\
\hline Rumex crispus & Curly dock & $\mathrm{N}$ \\
\hline Sinapis arvensis & Field mustard & $\mathrm{N}$ \\
\hline Sonchus arvensis & Field sowthistle & $\mathrm{N}$ \\
\hline Taraxacum officinale & Common dandelion & $\mathrm{N}$ \\
\hline Thlaspi arvense & Field pennycress & $\mathrm{N}$ \\
\hline Trifolium repens & White clover & \\
\hline
\end{tabular}




\begin{tabular}{l|l|c|}
$\begin{array}{l}\text { Scientific Name } \\
\text { Common Name }\end{array}$ & $\begin{array}{l}\text { Present in seed bank } \\
\text { analysis }\end{array}$ \\
\hline Urtica dioica & Stinging nettle & $\mathrm{N}$ \\
\hline Verbascum blattaria & Moth mullein & $\mathrm{Y}$ \\
\hline Veronica sp. & Speedwell & $\mathrm{N}$ \\
\hline
\end{tabular}

Group 3 (Potential problem nonnative)

\begin{tabular}{|l|l|c|}
\hline Alliaria petiolata & Garlic mustard & $\mathrm{Y}$ \\
\hline Artemisia vulgaris & Mugwort & $\mathrm{N}$ \\
\hline
\end{tabular}

Group 4 (purple loosestrife)

\begin{tabular}{|l|l|c|}
\hline Lythrum salicaria & Purple loosestrife & Y \\
\hline
\end{tabular}

Group 5 (phragmites)

Phragmites australis

\begin{tabular}{|l|c|}
\hline Common reed & $Y$ \\
\hline
\end{tabular}

Group 6 (cattails)

\begin{tabular}{|l|l|c|}
\hline Typha sp. & Cattail & $\mathrm{Y}$ \\
\hline
\end{tabular}

Group 7 (bare or debris)

\begin{tabular}{|l|l|c|}
\hline N/A & Bare/debris & N/A \\
\hline
\end{tabular}




\section{Appendix C: Relative Cover, Relative Frequency, and Importance Value Calculated for Vegetation Transects in Three Treatment Areas (TAs) at Times Beach, New York}

\begin{tabular}{|c|c|c|c|c|c|c|}
\hline \multicolumn{7}{|c|}{ Treatment Area 1 (glyphosate) } \\
\hline \multirow{2}{*}{ Metric } & \multirow{2}{*}{ Group } & \multicolumn{5}{|c|}{ Mean \pm Standard Error } \\
\hline & & Year 1 & Year 2 & Year 3 & Year 4 & Year 5 \\
\hline \multirow{7}{*}{ Cover } & Native & $4.8 \pm 0.3$ & $10.0 \pm 0.7$ & $17.8 \pm 2.9$ & $35.2 \pm 4.0$ & $29.7 \pm 9.0$ \\
\hline & Acceptable nonnative & $7.7 \pm 4.3$ & $17.5 \pm 0.3$ & $20.4 \pm 0.6$ & $15.0 \pm 3.7$ & $7.6 \pm 1.6$ \\
\hline & Potential problem nonnative & $0.0 \pm 0.0$ & $0.4 \pm 0.2$ & $0.7 \pm 0.7$ & $0.4 \pm 0.2$ & $0.2 \pm 0.1$ \\
\hline & Purple loosestrife & $0.0 \pm 0.0$ & $0.1 \pm 0.1$ & $0.4 \pm 0.2$ & $1.3 \pm 0.3$ & $1.6 \pm 0.0$ \\
\hline & Phragmites & $18.0 \pm 1.9$ & $13.8 \pm 4.7$ & $0.9 \pm 0.0$ & $8.9 \pm 3.6$ & $1.1 \pm 0.6$ \\
\hline & Cattails & $19.2 \pm 0.9$ & $14.2 \pm 0.2$ & $10.9 \pm 7.0$ & $25.4 \pm 5.2$ & $36.0 \pm 1.1$ \\
\hline & Bare/debris & $50.3 \pm 5.6$ & $44.1 \pm 5.4$ & $48.8 \pm 8.5$ & $13.9 \pm 2.4$ & $23.7 \pm 7.0$ \\
\hline \multirow{7}{*}{ Freq } & Native & $15.3 \pm 1.4$ & $17.0 \pm 1.8$ & $18.6 \pm 1.6$ & $36.4 \pm 3.5$ & $34.1 \pm 6.7$ \\
\hline & Acceptable nonnative & $24.0 \pm 5.4$ & $33.1 \pm 1.6$ & $43.2 \pm 0.7$ & $36.3 \pm 9.9$ & $17.2 \pm 2.4$ \\
\hline & Potential problem nonnative & $0.0 \pm 0.0$ & $1.4 \pm 0.6$ & $1.5 \pm 1.5$ & $2.4 \pm 1.7$ & $2.1 \pm 0.4$ \\
\hline & Purple loosestrife & $0.0 \pm 0.0$ & $1.2 \pm 0.5$ & $2.9 \pm 1.1$ & $4.8 \pm 0.4$ & $6.7 \pm 0.5$ \\
\hline & Phragmites & $13.5 \pm 0.7$ & $10.9 \pm 0.1$ & $3.7 \pm 0.2$ & $7.6 \pm 0.6$ & $3.6 \pm 0.8$ \\
\hline & Cattails & $18.2 \pm 3.9$ & $14.6 \pm 0.2$ & $11.0 \pm 3.6$ & $7.1 \pm 1.4$ & $15.2 \pm 1.6$ \\
\hline & Bare/debris & $29.0 \pm 3.6$ & $21.8 \pm 0.3$ & $19.1 \pm 0.2$ & $14.1 \pm 0.8$ & $21.2 \pm 3.3$ \\
\hline \multirow{7}{*}{ Importance } & Native & $20.1 \pm 1.6$ & $27.0 \pm 1.1$ & $36.4 \pm 1.3$ & $67.6 \pm 4.7$ & $63.8 \pm 15.7$ \\
\hline & Acceptable nonnative & $31.7 \pm 9.6$ & $50.7 \pm 1.3$ & $63.6 \pm 0.1$ & $46.9 \pm 9.1$ & $24.8 \pm 4.0$ \\
\hline & Potential problem nonnative & $0.0 \pm 0.0$ & $1.8 \pm 0.4$ & $2.2 \pm 2.2$ & $2.7 \pm 2.0$ & $2.3 \pm 0.5$ \\
\hline & Purple loosestrife & $0.0 \pm 0.0$ & $1.3 \pm 0.6$ & $3.3 \pm 1.3$ & $6.1 \pm 0.7$ & $8.3 \pm 0.5$ \\
\hline & Phragmites & $31.5 \pm 2.7$ & $24.6 \pm 4.8$ & $4.6 \pm 0.2$ & $16.5 \pm 3.0$ & $4.6 \pm 1.4$ \\
\hline & Cattails & $37.4 \pm 4.8$ & $28.8 \pm 0.0$ & $21.9 \pm 10.6$ & $32.5 \pm 6.6$ & $51.2 \pm 2.7$ \\
\hline & Bare/debris & $79.3 \pm 9.2$ & $65.8 \pm 5.1$ & $67.9 \pm 8.3$ & $28.0 \pm 1.6$ & $45.0 \pm 10.3$ \\
\hline
\end{tabular}




\begin{tabular}{|c|c|c|c|c|c|c|}
\hline \multicolumn{7}{|c|}{ Treatment Area 2 (glyphosate \& imazamox) } \\
\hline \multirow{2}{*}{ Metric } & \multirow{2}{*}{ Group } & \multicolumn{5}{|c|}{ Mean \pm Standard Error } \\
\hline & & Year 1 & Year 2 & Year 3 & Year 4 & Year 5 \\
\hline \multirow{7}{*}{ Cover } & Native & $0.1 \pm 0.1$ & $6.2 \pm 2.6$ & $36.2 \pm 0.3$ & $43.7 \pm 2.8$ & $33.6 \pm 5.4$ \\
\hline & Acceptable nonnative & $1.3 \pm 0.1$ & $24.6 \pm 6.0$ & $23.8 \pm 5.6$ & \pm 4.0 & \pm 3.6 \\
\hline & Potential problem nonnative & $0.0 \pm 0.0$ & $0.2 \pm 0.2$ & $0.5 \pm 0.5$ & \pm 0.0 & \pm 0.1 \\
\hline & Purple loosestrife & $0.0 \pm 0.0$ & \pm 0.1 & $6.7 \pm 1.9$ & $15.5 \pm 10.7$ & \pm 1.9 \\
\hline & Phragmites & $51.1 \pm 0.6$ & $32.5 \pm 3.8$ & $0.3 \pm 0.1$ & \pm 0.1 & \pm 0.2 \\
\hline & Catta & \pm 2.0 & $6.2 \pm 1.6$ & $0.5 \pm 0.5$ & $14.4 \pm 13.6$ & $10.6 \pm 10.6$ \\
\hline & Bar & $41.4 \pm 2.6$ & $30.0 \pm 8.9$ & $32.0 \pm 7.8$ & $16.1 \pm 1.8$ & $43.7 \pm 21.3$ \\
\hline \multirow{7}{*}{ Freq } & Native & $2.0 \pm 2.0$ & $13.1 \pm 0.9$ & $29.2 \pm 3.4$ & $41.7 \pm 2.6$ & $39.2 \pm 4.1$ \\
\hline & Acceptable nonnative & $6.9 \pm 1.3$ & $37.8 \pm 4.5$ & $41.8 \pm 3.4$ & $15.9 \pm 1.8$ & $21.5 \pm 2.6$ \\
\hline & Potential problem nonnative & $0.0 \pm 0.0$ & \pm 0.4 & $1.2 \pm 1.2$ & $0.3 \pm 0.3$ & \pm 0.7 \\
\hline & Purple loosestrife & $0.0 \pm 0.0$ & $3.9 \pm 1.4$ & $10.7 \pm 1.0$ & $10.5 \pm 0.9$ & \pm 0.5 \\
\hline & Phragmites & $39.2 \pm 2.5$ & $17.8 \pm 1.5$ & $1.5 \pm 0.2$ & $8.9 \pm 0.1$ & $4.9 \pm 0.9$ \\
\hline & Catta & $9.6 \pm 1.5$ & $6.3 \pm 1.0$ & $1.6 \pm 1.6$ & $6.7 \pm 2.9$ & $4.5 \pm 4.5$ \\
\hline & Bare & $42.3 \pm 0.6$ & $20.8 \pm 2.1$ & $14.1 \pm 0.7$ & $15.9 \pm 2.0$ & $20.3 \pm 2.7$ \\
\hline \multirow{7}{*}{ Importance } & Native & $2.2 \pm 2.2$ & $19.3 \pm 3.5$ & $65.4 \pm 3.7$ & $85.4 \pm 0.2$ & $72.7 \pm 1.3$ \\
\hline & Acceptable & \pm 1.2 & $62.4 \pm 10.5$ & $65.6 \pm 2.2$ & $24.5 \pm 5.8$ & $28.7 \pm 6.2$ \\
\hline & Potential problem nonnative & \pm 0.0 & $0.6 \pm 0.6$ & $1.6 \pm 1.6$ & $0.4 \pm 0.4$ & $0.8 \pm 0.8$ \\
\hline & Purple loosestrife & \pm 0.0 & $4.2 \pm 1.6$ & $17.3 \pm 2.8$ & $26.0 \pm 11.6$ & $11.9 \pm 1.4$ \\
\hline & Phragmites & $90.3 \pm 3.1$ & $50.2 \pm 2.3$ & $1.8 \pm 0.3$ & $10.7 \pm 0.1$ & $6.7 \pm 0.7$ \\
\hline & Cattails & $15.8 \pm 3.4$ & $12.5 \pm 2.6$ & $2.1 \pm 2.1$ & $21.1 \pm 16.5$ & $15.2 \pm 15.2$ \\
\hline & Bare/debris & $83.6 \pm 3.2$ & $50.7 \pm 11.0$ & $46.1 \pm 8.5$ & $32.0 \pm 0.2$ & $64.0 \pm 24.0$ \\
\hline
\end{tabular}

\begin{tabular}{|c|c|c|c|c|c|c|}
\hline \multicolumn{7}{|c|}{ Treatment Area 3 (imazamox) } \\
\hline \multirow{2}{*}{ Metric } & \multirow{2}{*}{ Group } & \multicolumn{5}{|c|}{ Mean \pm Standard Error } \\
\hline & & Year 1 & Year 2 & Year 3 & Year 4 & Year 5 \\
\hline \multirow{7}{*}{ Cover } & Native & $0.3 \pm 0.0$ & $2.1 \pm 0.1$ & $2.9 \pm 0.5$ & $19.3 \pm 0.8$ & $56.4 \pm 22.1$ \\
\hline & Acceptable nonnative & $0.3 \pm 0.3$ & $2.3 \pm 1.5$ & $1.5 \pm 0.9$ & $2.4 \pm 0.5$ & $4.0 \pm 1.0$ \\
\hline & Potential problem nonnative & \pm 0.0 & \pm 0.0 & \pm 0.0 & \pm 0.0 & \pm 7.8 \\
\hline & Purple loosestrife & \pm 0.0 & \pm 0.4 & \pm 1.3 & $5.1 \pm 4.6$ & \pm 1.7 \\
\hline & Phragmites & $14.5 \pm 12.1$ & $16.4 \pm 10.3$ & \pm 0.3 & \pm 0.2 & \pm 0.5 \\
\hline & Cattails & $29.8 \pm 10.8$ & $20.9 \pm 2.6$ & $36.8 \pm 8.2$ & $38.5 \pm 5.3$ & $11.8 \pm 11.3$ \\
\hline & Bare/debris & $55.2 \pm 1.6$ & $58.0 \pm 9.6$ & $56.2 \pm 6.2$ & $32.5 \pm 1.1$ & $17.5 \pm 17.3$ \\
\hline \multirow{7}{*}{ Freq } & Native & $3.5 \pm 0.3$ & $13.1 \pm 0.7$ & $14.0 \pm 0.2$ & $29.7 \pm 2.2$ & $34.2 \pm 7.2$ \\
\hline & Acceptable nonnative & \pm 2.3 & $11.7 \pm 7.3$ & $16.2 \pm 7.5$ & $19.1 \pm 11.0$ & $13.4 \pm 2.5$ \\
\hline & Potential problem nonnative & \pm 0.0 & \pm 0.0 & $0.0 \pm 0.0$ & $0.3 \pm 0.3$ & \pm 0.3 \\
\hline & Purple loosestrife & \pm 0.0 & \pm 2.9 & $4.7 \pm 3.1$ & $5.4 \pm 2.0$ & \pm 1.7 \\
\hline & Phragmites & $13.6 \pm 6.0$ & $14.4 \pm 2.0$ & \pm 1.1 & $6.8 \pm 0.6$ & $4.5 \pm 0.2$ \\
\hline & Cattails & $37.7 \pm 6.9$ & $26.0 \pm 7.7$ & $27.1 \pm 3.9$ & $20.3 \pm 2.5$ & $18.4 \pm 4.3$ \\
\hline & Bare/debris & $43.0 \pm 1.6$ & $32.0 \pm 5.2$ & $33.5 \pm 5.4$ & $27.4 \pm 3.5$ & $23.9 \pm 2.0$ \\
\hline \multirow{7}{*}{ Importance } & Native & $3.8 \pm 0.2$ & $15.1 \pm 0.6$ & $17.0 \pm 0.7$ & $49.0 \pm 1.4$ & $90.6 \pm 14.9$ \\
\hline & Acceptable nonnative & $2.5 \pm 2.5$ & $13.9 \pm 8.8$ & $17.7 \pm 8.4$ & $12.6 \pm 2.6$ & $17.4 \pm 3.4$ \\
\hline & Potential problem nonnative & $0.0 \pm 0.0$ & $0.0 \pm 0.0$ & $0.0 \pm 0.0$ & $0.3 \pm 0.3$ & $8.0 \pm 8.0$ \\
\hline & Purple loosestrife & $0.0 \pm 0.0$ & $3.4 \pm 3.4$ & $6.3 \pm 4.4$ & $10.5 \pm 6.6$ & $7.1 \pm 3.4$ \\
\hline & Phragmites & $28.1 \pm 18.1$ & $30.7 \pm 12.3$ & $5.3 \pm 0.9$ & $8.8 \pm 0.8$ & \pm 0.7 \\
\hline & Cattails & $67.5 \pm 17.6$ & $46.8 \pm 10.3$ & $63.9 \pm 12.1$ & $58.9 \pm 7.8$ & $30.2 \pm 7.0$ \\
\hline & Bare/debris & $98.2 \pm 3.2$ & $90.0 \pm 14.8$ & $89.7 \pm 0.9$ & $59.9 \pm 2.4$ & $41.4 \pm 15.3$ \\
\hline
\end{tabular}




\section{Appendix D: Nonmetric Multidimensional Scaling (NMDS) Ordination of Sampling Sites Based on Vegetation Relative Cover with Bubble Plot Overlay Showing Mean Vegetation Cover Class at Each Sampling Location}

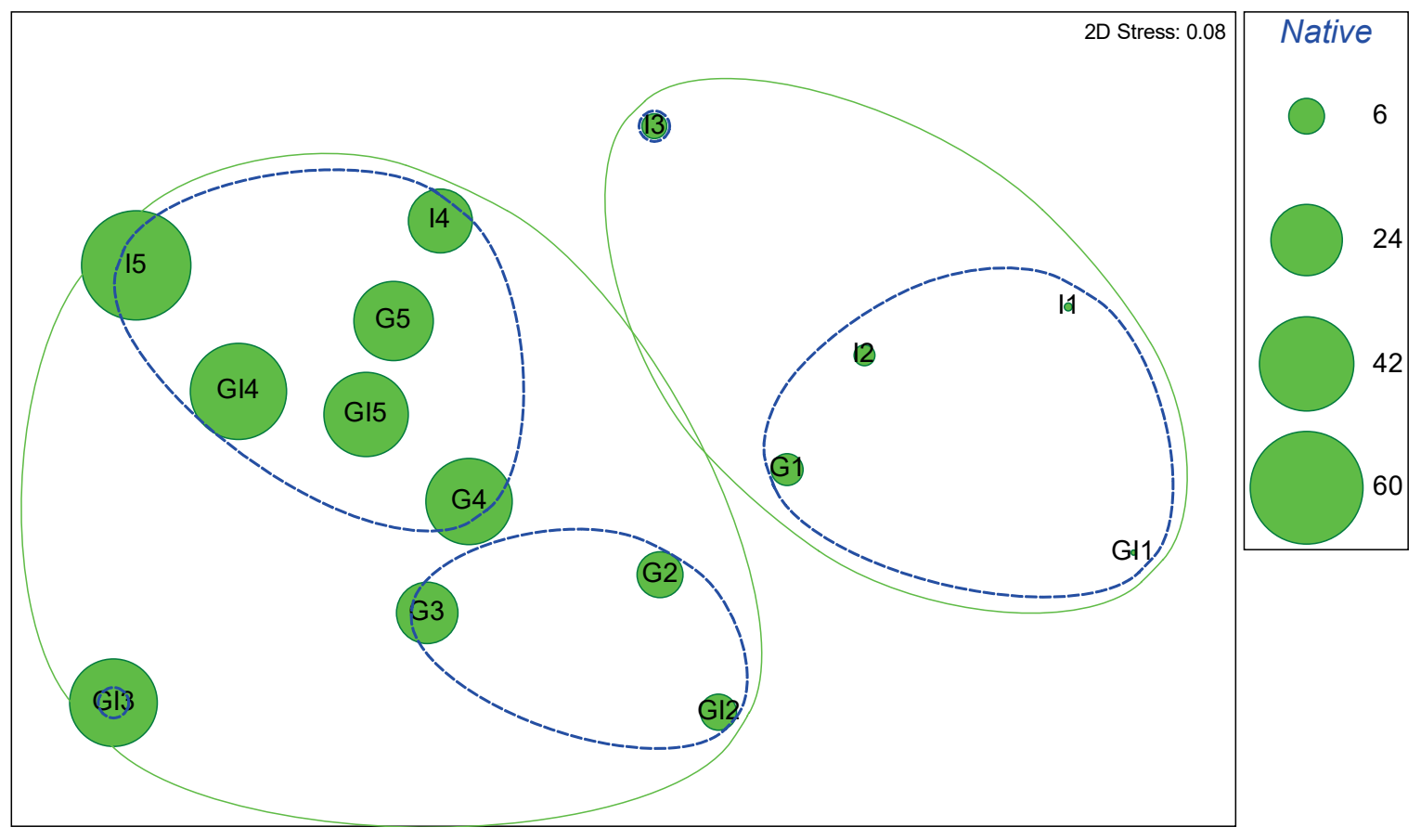



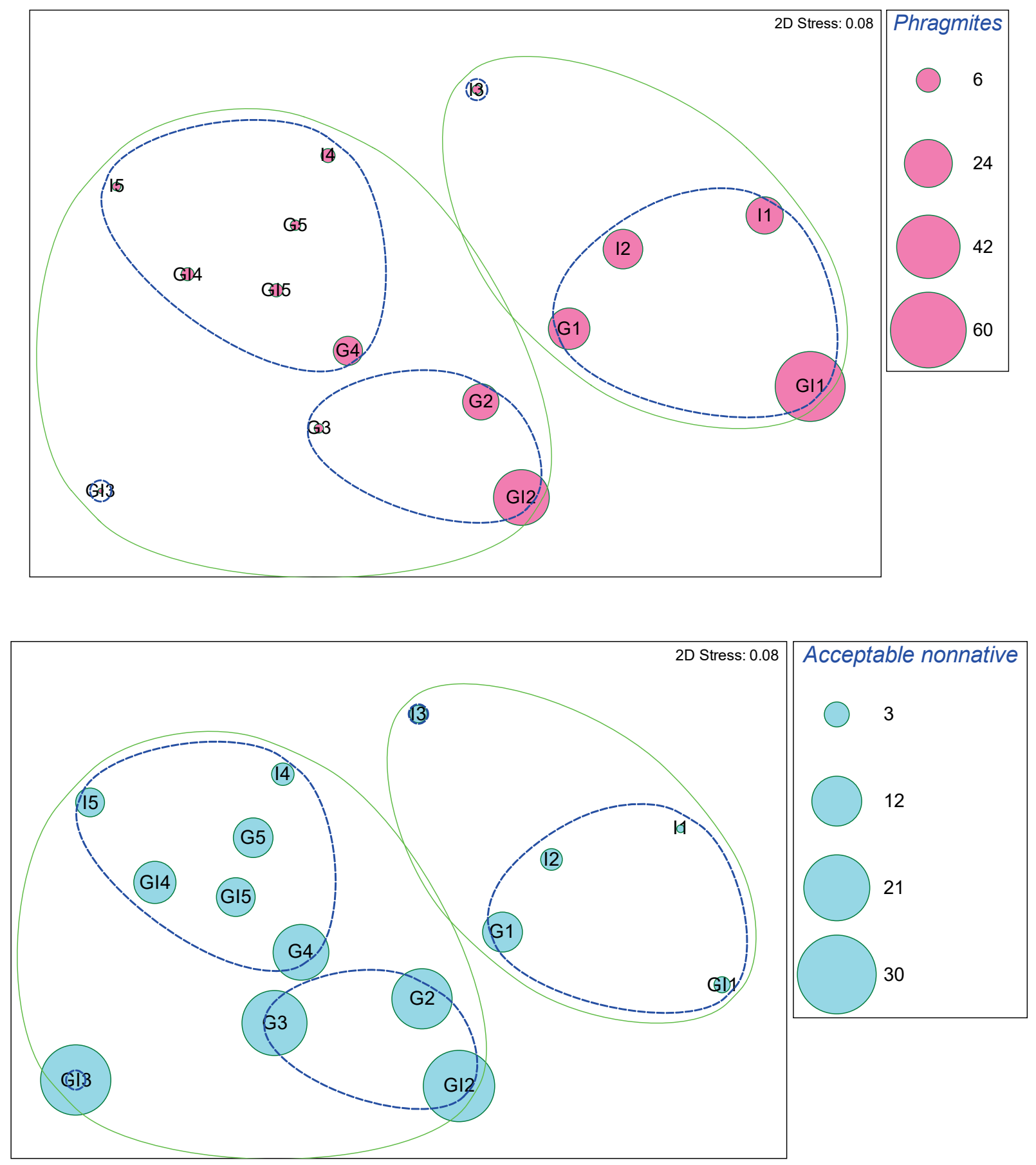

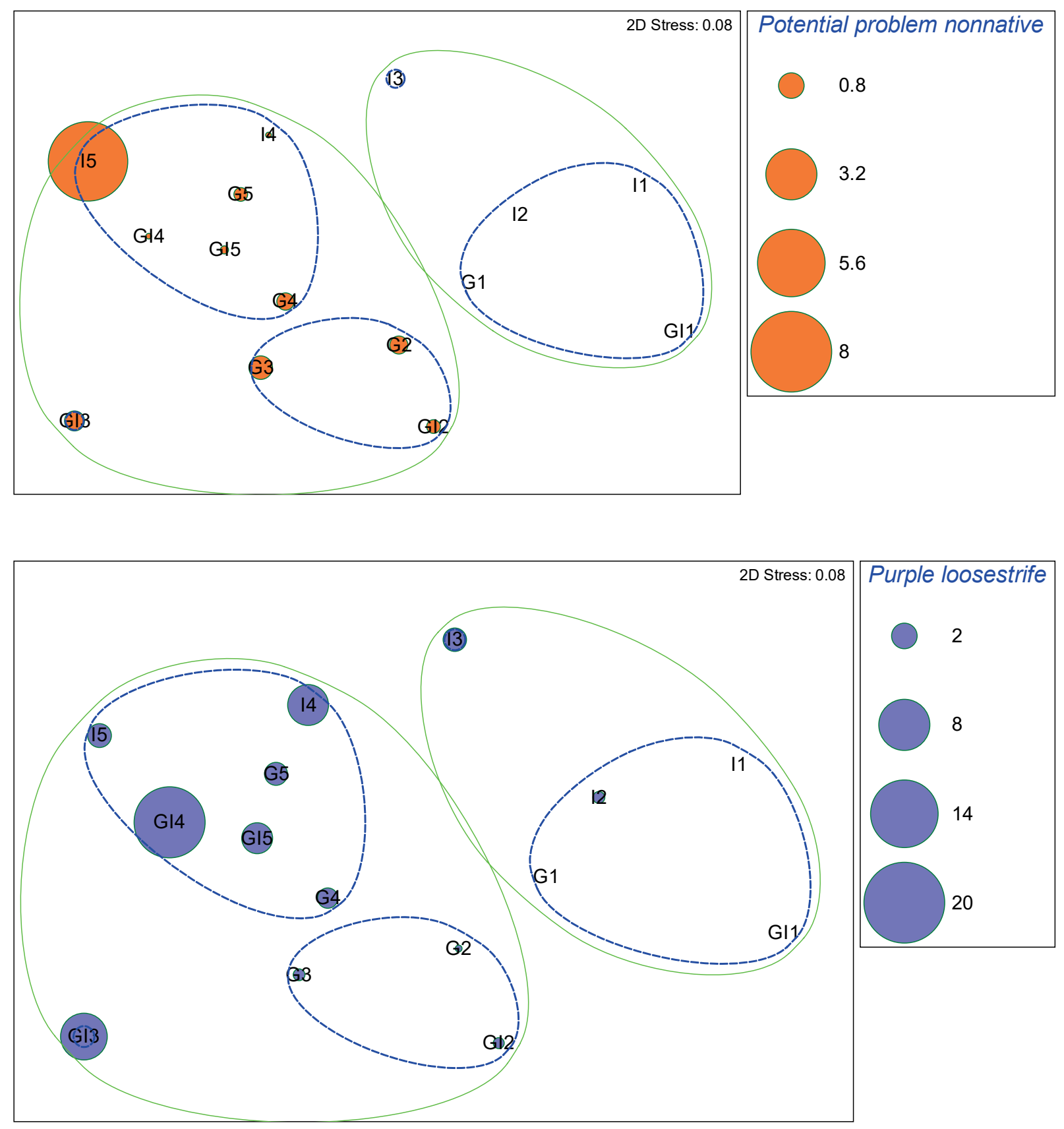

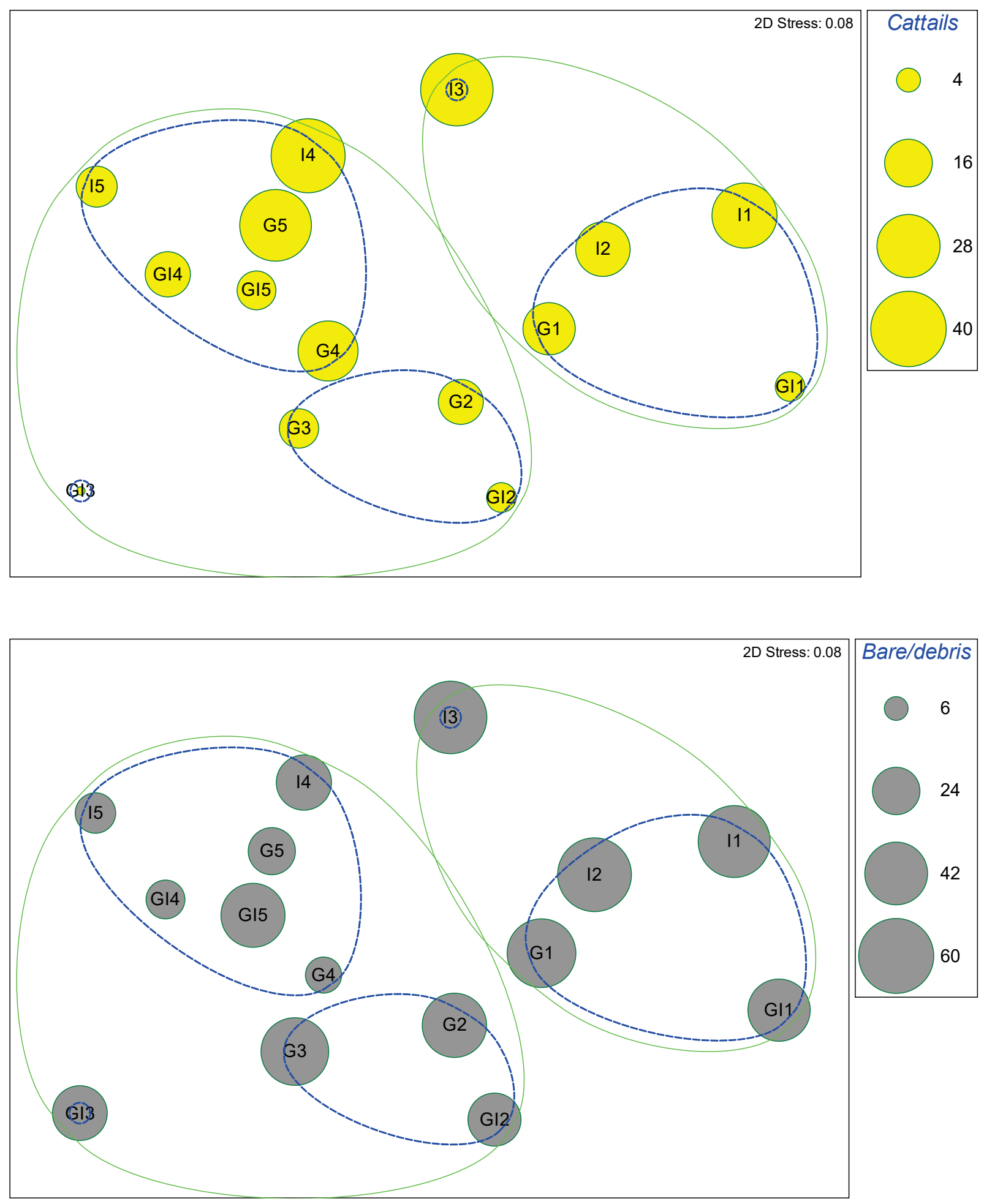


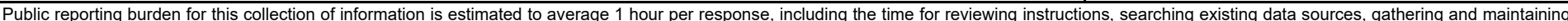

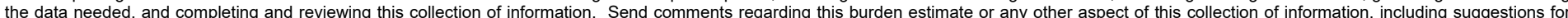

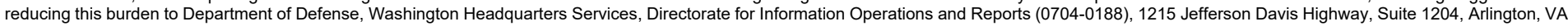

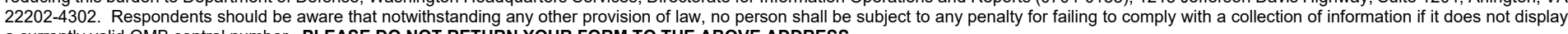
a currently valid OMB control number. PLEASE DO NOT RETURN YOUR FORM TO THE ABOVE ADDRESS.
1. REPORT DATE (DD-MM-YYYY)
2. REPORT TYPE
September 2021
Special Report

\section{TITLE AND SUBTITLE}

Vegetation Community Changes in Response to Phragmites Management at Times Beach,

Buffalo, New York

3. DATES COVERED (From - To)

5a. CONTRACT NUMBER

5b. GRANT NUMBER

5c. PROGRAM ELEMENT NUMBER

6. AUTHOR(S)

Aaron N. Schad, Gary O. Dick, Kris Erickson, Paul Fuhrmann, and Lynde L.Dodd

5d. PROJECT NUMBER

5e. TASK NUMBER

5f. WORK UNIT NUMBER

\section{PERFORMING ORGANIZATION NAME(S) AND ADDRESS(ES)}

US Army Engineer Research and Development Center

Environmental Laboratory

3909 Halls Ferry Road

Vicksburg, MS 39180
Ecology and Environment, Inc.

368 Pleasant View Drive

Lancaster, NY 14086
8. PERFORMING ORGANIZATION REPORT NUMBER

ERDC/EL SR-21-7

9. SPONSORING / MONITORING AGENCY NAME(S) AND ADDRESS(ES)

10. SPONSOR/MONITOR'S ACRONYM(S)

U.S. Army Corps of Engineers, Headquarters

441 G St. NW

Washington, DC 20314-1000

11. SPONSOR/MONITOR'S REPORT NUMBER(S)

\section{DISTRIBUTION / AVAILABILITY STATEMENT}

Approved for public release; distribution is unlimited.

\section{SUPPLEMENTARY NOTES}

Funding Account Code U4351109; AMSCO Code 099993.

\section{ABSTRACT}

Management of invasive phragmites (Phragmites australis [Cav.] Trin. Ex Steud.) in the United States has proven challenging over the last several decades. Various methods for control exist, but integrated approaches appear to have the most success. However,

documentation of vegetation community-wide responses to these approaches remains limited.

This study monitored plant community changes at Times Beach, New York, over a five-year period. In concert with mowing and thatch removal in all areas, the study evaluated two herbicides separately and together, representing three experimental treatment areas (TAs), for control efficacy by measuring plant community structure. Phragmites was targeted for treatments, avoiding native and nonproblematic non-native species when possible, to preserve beneficial habitat during phragmites control efforts. Monitoring results showed significant drops in phragmites relative cover, relative frequency, and importance values due to integrated management, regardless of herbicide treatment, with corresponding increases in these same values for native and other plant species. This suggests that prudent removal of phragmites is compatible with beneficial plant restorative efforts to maintain and improve habitat in infested areas.

\section{SUBJECT TERMS}

Aquatic plants

16. SECURITY CLASSIFICATION OF:

\section{a. REPORT}

Unclassified

\section{b. ABSTRACT}

Unclassified

\section{c. THIS PAGE}

Unclassified

\begin{tabular}{c|c}
$\begin{array}{c}\text { 17. LIMITATION } \\
\text { OF ABSTRACT }\end{array}$ & $\begin{array}{c}\text { 18. NUMBER } \\
\text { OF PAGES }\end{array}$ \\
SAR & 36
\end{tabular}

19a. NAME OF RESPONSIBLE PERSON

19b. TELEPHONE NUMBER (include area code) 